\title{
АДАПТАЦИЯ И УСТОЙЧИВОСТЬ РАСТЕНИЙ ПШЕНИЦЫ К ЗАСУХЕ, ОПОСРЕДОВАННАЯ ПРИРОДНЫМИ РЕГУЛЯТОРАМИ РОСТА Bacillus spp.: МЕХАНИЗМЫ РЕАЛИЗАЦИИ И ПРАКТИЧЕСКАЯ ЗНАЧИМОСТЬ* (обзор)
}

\section{О.В. ЛАСТОЧКИНА}

Абиотические факторы среды, приводящие к дефициту влаги, значительно ограничивают производство основных сельскохозяйственных культур во всем мире (Z. Ahmad с соавт., 2018). В условиях быстрого роста численности населения и изменения климата важно обеспечить продовольственную безопасность, которая в основном возможна за счет повышения продуктивности стратегически важных зерновых культур, включая пшеницу, которая используется человеком во многих регионах мира и обеспечивает более 50 \% потребности в пищевой энергии (S. Asseng c соавт., 2019). Использование полезных стимулирующих рост бактерий Bacillus spp. рассматривается как эффективная, экологичная и безопасная природная стратегия защиты растений от стрессов, приводящих к дефициту влаги (М. Kaushal с соавт., 2019; A. Hussain с соавт., 2020; М. Camaille с соавт., 2021). К настоящему времени ростостимулирующий и защитный эффект Bacillus spp. в условиях различных абиотических стрессов показан для многих видов растений (S. Moon c соавт., 2017; H.G. Gowtham с соавт., 2020; N. Shobana с соавт., 2020), включая пшеницу (G. Sood c coaвт., 2020; U. Rashid с coaвT., 2021). Хотя механизмы такого физиологического действия Bacillus spp. на растения-хозяева в большей степени остаются неизвестными, предполагается, что они включают і) конкуренцию за пространство и питательные вещества с фитопатогенами и повышение доступности макро- и микроэлементов (S. Danish с coaвт., 2019; D. Miljakovic с coaвт., 2020; А. Kumar с соавт., 2021); ii) продукцию широкого спектра биологически активных компонентов и защитных соединений (M. Saha с соавт., 2016; R. Çakmakçı с соавт., 2017; N. Ilyas c соавт., 2020) и iii) индукцию у растений реакций системной устойчивости к стрессам (I.A. Abd ElDaim с соавт., 2019; С. Blake с соавт., 2021; U. Rashid с соавт., 2021). Вместе с тем эффективность применения одного и того же штамма Bacillus spp. может варьироваться в зависимости от многих факторов, включая спектр синтезируемых штаммами соединений, вид растений, их эколого-географическое происхождение, сортовые особенности, виды стрессов, которым подвергаются растения в период вегетации, и многое другое (А. Khalid с соавт., 2004; G. Salem с coaвт., 2018; O. Lastochkina с соавт., 2020b). В настоящем обзоре обобщена информация, касающаяся современного состояния исследований и представлений о растительно-микробных взаимодействиях с точки зрения защиты пшеницы от засухи. В частности, рассмотрены механизмы, лежащие в основе Bacillus-опосредованной адаптации и устойчивости растений пшеницы к дефициту влаги, включающие синтез осмопротекторных и снижающих окислительный стресс соединений (R. Çakmakçı c coaвт., 2017), внутриклеточную передачу и усиление защитных сигналов каскадом посредников, а также регуляцию экспрессии генов защитных белков и межорганную трансдукцию при участии основных фитогормонов и их биосинтеза в целом растении (U. Rashid с соавт., 2021), многочисленных соединений, вовлеченных в процессы повышения биодоступности макро- и микроэлементов и продуктивности (A. Hussain с соавт., 2020; А. Kumar с соавт., 2021). Обсуждается влияние Bacillus spp. на параметры фотосинтеза и водного обмена растений (I.A. Abd El-Daim с соавт., 2019), а также их эффективность в засухоустойчивости пшениц разных агроэкологических групा (Л.И. Пусенкова с соавт., 2020). Затронут вопрос совместного применения бактерий Bacillus spp. с другими природными регуляторами роста с целью повышения их эффективности и сохранения стабильности действия (M. Zafar-ulНуе с соавт., 2019), а также приведены примеры коммерциализации бациллярных препаратов и их эффективности на пшенице. Представленные в обзоре сведения вносят вклад в понимание фундаментальных механизмов взаимодействия Bacillus spp. с растениями пшеницы в условиях дефицита влаги и могут быть использованы для разработки бациллярных биопрепаратов и их внедрения в экологически ориентированные технологии выращивания пшеницы в условиях меняющегося климата.

Ключевые слова: ростостимулирующие бактерии, Bacillus spp., пшеница, засуха, защитные механизмы, растительно-микробные взаимодействия, индуцированная системная устойчивость.

Пшеница мягкая (Triticum aestivum L.) - основная стратегически важная сельскохозяйственная культура среди зерновых, используемая для потребления человеком во многих регионах мира и играющая ключевую

* Работа выполнена при финансовой поддержке РФФИ в рамках научного проекта № 20-116-50151. 
роль в обеспечении более 50 \% потребности в пищевой энергии (1-4). K числу доминирующих абиотических стрессов, препятствующих росту и потере урожайности (до 50-80 \%) пшеницы, относится засуха, которой подвержены около 64 \% мировых сельскохозяйственных земель (2-5). Засуха, пагубно влияя на общий метаболизм растений на физиологическом, биохимическом и молекулярном уровнях, приводит к повреждению различных клеточных компартментов, деградации белков, инактивации ферментов, снижению поглощения питательных веществ, транспирации и скорости фотосинтеза, закрытию устьиц, торможению роста, увяданию и высыханию растений (4-6). Хотя растения обладают различными системами защиты для противодействия внешним угрозам, этих средств недостаточно, вследствие чего при засухе наблюдаются значительные потери урожая у всех видов сельскохозяйственных культур, включая пшеницу (4). Согласно прогнозам, интенсивность засухи будет последовательно увеличиваться, что в сочетании с экспоненциальным ростом населения планеты лишь усугубляет эту проблему и требует ее безотлагательного решения для предотвращения надвигающейся продовольственной катастрофы $(2,7)$. Химические средства защиты растений негативно сказываются на окружающей среде и здоровье человека вследствие высокой токсичности и способности накапливаться в продукции и почвах, что в сочетании с изменениями климата и ростом населения планеты $(1,2)$ ведет к необходимости сокращать применение химических препаратов. Это серьезная проблема, для решения которой предпринимаются меры по повышению стрессоустойчивости растений посредством генетической модификации и традиционной селекции (8), что, однако, требует много времени, значительных финансовых средств и связано с многочисленными нормативными ограничениями. Применение полезных микроорганизмов, стимулирующих рост растений (PGPB, Plant Growth-Promoting Bacteria) (9-12), в частности рода Bacillus spp., способных активировать естественные защитные механизмы растений-хозяев, не вызывая негативного воздействия на них, окружающую среду и здоровье человека, рассматривают как доступную, дешевую, быстродействующую и экологически благоприятную альтернативную биологическую стратегию повышения адаптивного потенциала (13-16) и урожайности растений в изменяющихся условиях среды с одновременным восстановлением здоровья почвы $(17,18)$.

PGPB Bacillus spp. - большая и разнообразная группа полезных непатогенных микроорганизмов, свободно живущих в почве либо населяющих поверхность (ризосферу и филосферу) или внутреннюю часть тканей (эндофиты) растений-хозяев, способных индуцировать рост и устойчивость растений к биотическим стрессорам - фитопатогенам (19-22), насекомым-вредителям (20), нематодам (19), вирусам (20) и абиотическим стрессам - засухе $(17,24)$, засолению (11), перепадам температур (12), токсичным соединениям (14), УФ-излучению $(12,13)$. Это продемонстрировано на примере многих видов растений $(17,25-28)$, включая пшеницу (13, 29-31). Хотя фундаментальные механизмы физиологического действия Bacillus spp. на растения в большей степени остаются неясными, известно, что они прямыми или непрямыми взаимосвязанными путями модулируют гормональный фон, влияющий на архитектуру корневой системы (32-35), улучшают биодоступность макро- и микроэлементов и минеральное питание растений (биофиксация азота, солюбилизация фосфора, калия, цинка и других элементов) (36-39), фотосинтез $(40,41)$, устьичную проводимость $(17,42)$, водный статус $(17,42,43)$, регулируют про- 
дукцию фитогормонов - ауксинов, цитокининов, гиббереллинов, абсцизовой (АБК), салициловой (СК), жасмоновой (ЖК) кислот, этилена и их накопление в растении $(23,44-46)$, активируют синтез различных антиоксидантных и осмопротекторных соединений $(27,47,48)$, экспрессию чувствительных к засухе генов аквапоринов, дегидринов $(25,41)$, продукцию летучих органических соединений, экзополисахаридов $(49,50), 1$-аминоциклопропан-1-карбоксилат-дезаминазы (АЦК-дезаминазы) (44, 51-53), органических кислот, спектра вторичных метаболитов (41) и сигнальных защитных соединений, активирующих в растении-хозяине индуцированную системную защиту $(25,35,42,52)$, что приводит к повышению устойчивости и продуктивности растений в условиях засухи (17). Наряду с этим Bacillus spp., в частности B. subtilis, - общепризнанно безопасные микроорганизмы для применения в пищевой промышленности (GRAS Generally Recognized As Safe) $(12,13,16)$. Кроме того, они продуцируют эндоспоры, чрезвычайно толерантные к разным физическим и химическим воздействиям (нагревание, высыхание, органические растворители, УФ-облучение и др.), благодаря чему сохраняют способность запускать защитные реакции у растений-хозяев даже в стрессовых условиях среды (19). Все это делает Bacillus spp. привлекательными агентами для разработки на их основе коммерческих биоудобрений и средств защиты растений, число которых растет ежегодно во всем мире. Однако на практике их эффективность часто варьирует в зависимости от многих факторов (характеристика штамма микроорганизма, вид растения, место его произрастания, сортовые особенности) $(13,34,54,55)$. Для более полного использования потенциала представителей Bacillus spp. в качестве инокулянтов, обеспечивающих устойчивую продуктивность растениеводства (особенно на фоне постоянного изменения климата), чрезвычайно важно понимать особенности этих растительно-микробных взаимодействий и механизмы, лежащие в основе физиологического эффекта, которые бациллы оказываю на растения, в частности при защите от доминирующих стрессовых факторов среды.

Цель настоящего обзора - обобщение сведений о фундаментальных механизмах адаптации и стрессоустойчивости, обусловленных действием Bacillus spp., и их роли в практическом улучшении роста и сохранении урожайности пшеницы в условиях засухи.

Согласно современным представлениям, бактерии Bacillus spp. способствуют более эффективному противостоянию растений стрессам благодаря развитию микроб-индуцированной системной толерантности (MicrobeInduced Systemic Tolerance, MIST) $(27,42,52)$. Она включает широкий спектр прямых и непрямых сложных взаимосвязанных механизмов, действие которых вызывает различные морфофизиологические и биохимические изменения и, снижая последствия стрессовой нагрузки на растения, приводит к повышению урожайности (рис.).

Модификация архитектуры корней и повышение доступности элементов минерального питания. Основной адаптивный механизм Bacillus-опосредованной стимуляции роста растений пшеницы в условиях засухи состоит в способности бацилл, колонизируя внешние (ризобактерии) и(или) внутренние (эндобактерии) ткани растений-хозяев, позитивно модулировать метаболизм растений и изменять архитектуру их корневой системы (увеличение длины основного и боковых корней, густоты корневых волосков, площади поверхности корней и накопление их биомассы) $(23,34)$, что способствует улучшению усвоения воды и пита- 
тельных веществ из почвы $(28,35,40,43)$. Bacillus spp. увеличивают доступность для растений и усвояемость элементов минерального питания благодаря биофиксации атмосферного и вносимого с минеральными удобрениями $\mathrm{N}$, что способствует уменьшению доз вносимых удобрений (3, $13,28,41)$. Сообщается и об участии B. subtilis в стимуляции деятельности других ризосферных азотфиксаторов $(23,56)$. Наряду с $\mathrm{N}$, рост растений напрямую зависит от Р, большое количество которого (более 80 \%) фиксируется в почве и недоступно для поглощения растениями из-за адсорбции, осаждения или преобразования. Bacillus spp. способны растворять не растворимые в воде и недоступные растениям формы почвенных соединений фосфора за счет продукции органических и неорганических кислот, сидерофоров, протонов, гидроксильных ионов и $\mathrm{CO}_{2}$, которые хелатируют катионы или снижают рН для высвобождения фосфора, а также других биологически активных соединений, солюбилизирующих соединения Р и способствующих их усвоению растениями $(23,57,58)$. Показано, что с присутствием N-фиксирующих и Р-солюбилизирующих Bacillus spp. напрямую связано поглощение питательных веществ и последующая стимуляция роста растений пшеницы $(23,58,59)$. Так, инокуляция B. subtilis SIR1 улучшала усвоение растениями пшеницы NPK при разной интенсивности засухи и увеличивала содержание этих элементов в растениях (17). Исследование M. Zafar-ul-Нуе с соавт. (44) показало, что B. amyloliquefaciens солюбилизируют $\mathrm{P}, \mathrm{K}$, что приводит к обогащению побегов и зерен пшеницы этими элементами. В других работах инокуляция пшеницы штаммами B. aryabhattai MDSR7, MDSR11 и MDSR14 значительно повышала доступность Zn для растений, их рост и накопление этого элемента в зернах усиливались (60). Для многих представителей Bacillus spp. выявлена способность к образованию положительно влияющих на рост растений биосурфактантов - веществ липопептидной природы с поверхностно-активными свойствами, способных снижать коэффициент межфазного натяжения и эмульгировать труднорастворимые гидрофобные соединения, повышая их доступность для растений $(13,16,19)$. Для удовлетворения потребностей в Fe у Bacillus spp. развились весьма специфические пути с участием низкомолекулярных хелатов $\mathrm{Fe}-$ сидерофоров, которые, переводя Fе в доступную для клеток форму, повышают его доступность для растений и усвояемость $(38,61)$.

Модуляция процессов фотосинтеза и водного обмена. Во время засухи кардинально снижается водный потенциал почвы, усиливается фотодыхание, закрываются устьица, снижается фотосинтез, происходит обезвоживание клеток и гиперпродукция активных форм кислорода (АФК), что в конечном итоге вызывает вторичные стрессы - осмотический и окислительный, ведущие к торможению роста растений и даже их гибели $(4,62)$ (см. рис.). Для многих штаммов Bacillus spp. показана способность поддерживать в растениях при засухе повышенное относительное содержание воды. Это важный физиологический параметр, коррелирующий с засухоустойчивостью $(17,42)$. Основные физиологические критерии оценки состояния растений во время засухи также включают устьичную проводимость, содержание хлорофилла, скорость фотосинтеза, соотношение величин переменной флуоресценции $\left(\mathrm{F}_{\mathrm{v}}\right)$ и максимальной флуоресценции $\left(\mathrm{F}_{\mathrm{m}}\right)$, содержание биомаркеров окислительного и осмотического статуса клеток - соответственно конечного продукта перекисного окисления липидов малонового диальдегида (МДА) и осмолита пролина (17). Сообщается о позитивном влиянии Bacillus spp. на содержание хлорофилла, устьичную проводимость, эффективность фотосистемы II в 
растениях пшеницы в условиях засухи (17), в первую очередь за счет улучшения состояния гидратации и профиля питания, сохраняющих клеточный тургор и запускающих защитные механизмы растений (42). Показано, что Bacillus-индуцированное улучшение водного статуса у пшеницы при стрессе способствует повышению скорости фотосинтеза, поскольку бо́льшая проводимости устьиц приводит к усилению диффузии $\mathrm{CO}_{2}$ в клетках мезофилла (40). Бактеризация штаммом B. subtilis LDR2 увеличивала засухоустойчивость пшеницы, поддерживая повышенную фотосинтетическую активность растений, способствуя накоплению ИУК, но снижая уровень АБК и АЦК (63). В инокулированных LDR2 и подвергнутых засухе проростках повышалась экспрессия генов TaCTR1 и TaDREB2, ответственных за формирование устойчивости пшеницы к абиотическим стрессам (63). Согласно другим данным, проявление защитного эффекта B. velezensis 5113 в отношении пшеницы при засухе было связано со способностью сохранять фотосинтетический аппарат растений, поддерживая более высокое содержание фотосинтетических пигментов (41).

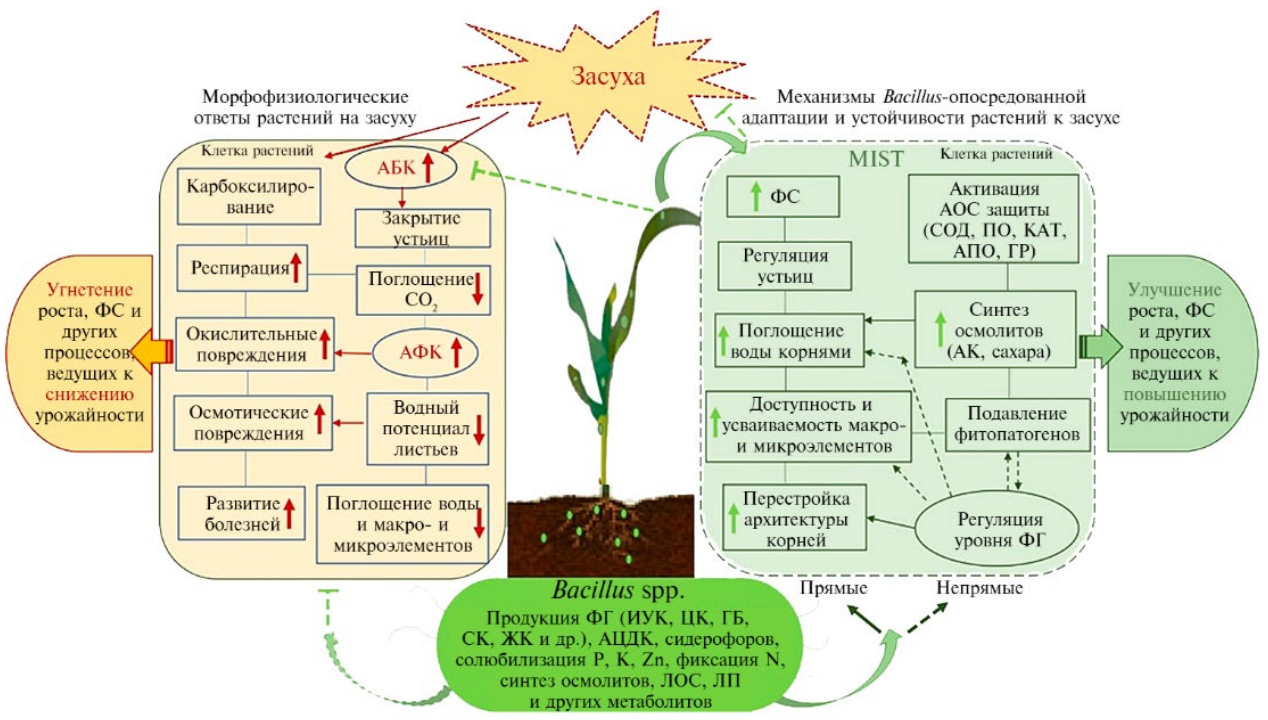

Основные механизмы Bacillus-опосредованной адаптации и устойчивости растений пшеницы к засухе: ФГ - фитогормоны, АБК - абсцизовая кислота, АК - аминокислоты, АОС - антиоксидантная система, АФК - активные формы кислорода, АЦКД - 1-аминоциклопропан-1карбоксилат-дезаминаза, ГБ - гиббереллины, ЖК - жасмоновая кислота, ИУК - индолил3-уксусная кислота, ЛОС - летучие органические соединения, ЛП - липопептиды, СК салициловая кислота, СОД - супероксиддисмутаза, ПО - пероксидаза, КАТ - каталаза, АПО - аскорбатпероксидаза, ГР - глутатионредуктаза, ФС - фотосинтез, ЦК - цитокинины, MIST - микроб-индуцированная системная устойчивость.

Мощным защитным механизмом Bacillus-опосредованного преодоления осмотического стресса и поддержания водного статуса растений в условиях засухи служит продукция и накопление бактериями Bacillus spp. ряда полярных метаболитов, в том числе многих аминокислот, например пролина и глицинбетаин, и сахаров - глюкозы, сахарозы и фруктозы (26, 35, 41). Осмолиты, продуцируемые Bacillus spp., вовлекаются в осмотическую регуляцию клеток и поддерживают необходимый клеточный тургор через снижение водного потенциала растений без уменьшения в них фактического содержания воды $(13,26,35,42)$. К основным осмолитам, которые синтезируются и накапливаются в растении в результате гидролиза белка при воздействии засухи, относится аминокислота пролин. Пролин выпол- 
няет множество функций, включая регулирование кислотности цитозоля, минимизацию перекисного окисления липидов за счет улавливания свободных радикалов и стабилизацию субклеточных компонентов и структур (белков и мембран). Вовлечение пролина в спектр механизмов защитного действия Bacillus spp. у различных видов дикорастущих и культурных растений, включая пшеницу, продемонстрировано в ряде исследований $(3,11,16)$. Однако открытым остается вопрос, с чем связано Bacillus-индуцированное повышение содержания пролина в растениях - с его более активным всасыванием из ризосферы или же с регуляцией биосинтеза в растениях (35). Имеются данные, указывающие на повышение засухоустойчивости пшеницы под влиянием Bacillus spp. с участием различныех других осмолитов (26). К примеру, выявлено существенное повышение засухоустойчивости растений при инокуляции штаммами PGPB, обладающими способностью к сверхпродукции трегалозы и(или) усиливающими ее накопление внутри растений (64). Известно, что трегалоза играет ключевую роль в передаче сигналов в клетке и стабилизации клеточных структур и белков $(42,65)$. Важное место в поддержании некоторыми штаммами Bacillus spp. осмотического баланса и защиты внешних белков в фотосистеме II во время абиотических стрессов может занимать глицинбетаин (35). Так, обнаружена способность B. subtilis GB03 усиливать в растениях биосинтез холина (первичного метаболита биосинтеза глицинбетаина) и накопление глицинбетаина, что сопровождалось повышением относительного содержания воды в листьях и накоплением сухой массы растений $(35,47)$. B. subtilis-индуцированное накопление глицинбетаина (2-кратное) и холина (5-кратное) придавало засухоустойчивость арабидопсису, тогда как в его мутантных линиях xipotl с нарушенным биосинтезом холина индуцированная B. subtilis засухоустойчивость утрачивалась $(42,47)$. В ряде исследований подтверждена осмопротекторная роль сахаров в инокулированных PGPB растениях при засухе (42). Для некоторых штаммов Bacillus spp. выявлена способность увеличивать накопление растениями полиаминов (кадаверина, спермидина, спермина и путресцина) - основных метаболитов, повышающих осмоустойчивость растений в условиях засухи (в дополнение к ключевой роли этих соединений в дифференцировке клеток, удлинении корней и регуляции транскрипции) $(35,66)$. Инокуляция B. megaterium BOFC15 увеличивала накопление полиаминов в растениях, что приводило к опосредованной полиаминами активации сигнальных путей, которые смягчали повреждающее действие засухи за счет поддержания повышенного количества воды в растении и фотосинтетической активности (66). Описана роль кадаверина и спермидина в усилении роста корней у PGPB-обработанных растений во время осмотического стресса $(23,35)$. Например, повышение содержания полиаминов наблюдали у растений арабидопсиса, обработанных продуцирующим спермидин штаммом B. megaterium BOFC15 (66). Растения смогли пережить засуху благодаря крепкой корневой системе, имеющей более длинные первичные и боковые корни по сравнению с контрольными образцами (66). Анализ фильтрата культуры B. subtilis OKВ105 подтвердил, что основным ростостимулирующим соединением оказался полиамин спермидин, в секрецию которого были вовлечены гены уес $A$ и $s p e B$, кодирующие полиаминпермеазу и агматиназу (16). Индуцированная ОКВ105 экспрессия генов экспансинов (Nt-EXPA1, Nt-EXPA2) ингибировала экспрессию гена биосинтеза этилена $A C O 1$ (14). Профили транскрипции B. subtilis показали, что гены, связанные с ацетилированием, транспортом и биосинтезом полиамиаминов, дифференциально экспрессируются при выращивании в щелочных или кислых условиях. Анализ литературы также указывает на существование 
связи между полиаминами и образованием биопленок, играющих важную роль в защите растений-хозяев (16), а также корреляции между количеством полиаминов, АБК и абиотическими стрессами (66). Это научное направление представляет интерес для раскрытия механизмов MIST, связанных с засухой (42). Недавние метаболомные исследования выявили накопление белков дегидринов и ряда других осмопротекторных соединений в инокулированных бациллами растениях в условиях стресса (41). В частности, штамм B. amyloliquefaciens GB03 смягчал осмотический стресс, активируя чувствительные к засухе гены дегидринов и аквапоринов, изменяя гормональный гомеостаз и усиливая продукцию антиоксидантных ферментов и экзополисахаридов $(27,48)$. Сообщалось, что продуцируемые бактериями экзополисахариды участвуют в колонизации корней, улучшают водоудерживающую способность растений и фертильность почвы, а также служат для защиты самих бактериальных клеток от высыхания $(50,67)$. Кроме того, растения, инокулированные продуцирующими экзополисахарид PGPB, показали более высокое накопление пролина, сахаров и аминокислот в условиях водного стресса $(50,67)$.

Активация систем антиоксидантной защиты. Известно, что засуха приводит к нарушению баланса между образованием АФК (супероксидного радикала, пероксида водорода и гидроксильного радикала) и их нейтрализацией $(4,68)$. Избыточные количества АФК начинают самопроизвольно и неспецифически взаимодействовать с молекулярными клеточными компонентами, что приводит к серьезным нарушениям клеточных структур, липидов, белков, углеводов, нуклеиновых кислот $(62,68)$. К важнейшим механизмам засухоустойчивости растений, опосредованной бактериями рода Bacillus, относится участие этих микроорганизмов в обезвреживании АФК посредством модуляции естественных систем антиоксидантной защиты растений - как ферментативных (супероксиддисмутаза, СОД; пероксидаза, ПО; каталаза, КАТ; аскорбатпероксидаза, АПО; глутатионредуктаза, ГР), так и неферментативных (аскорбиновая кислота, АК; глутатион, цистеин, пролин, флавоноиды, каротиноиды и токоферол), все компоненты которой находятся в сложном функциональном взаимодействии $(6,35)$ (см. рис.). Сообщалось об увеличении активности антиоксидантных ферментов (СОД, ПО, КАТ) в растениях при инокуляции Bacillus spp. как основном механизме MIST-защиты против засухи $(13,17,35,42)$. Кроме того, обработка B. amyloliquefaciens 5113 оказывала защитный эффект на растения пшеницы при засухе посредством регуляции активности гена АПО АРX1 и ферментов аскорбат-глутатионового комплекса, который, как известно, благодаря высоком внутриклеточному содержанию АК и глутатиона обеспечивает высокую буферную окислительно-восстановительную способность клеток и служит ключевым игроком в антиоксидантной системе защиты (68). Интересно, что в норме обработка $B$. velezensis 5113 практически не оказывала влияния на аскорбат-глутатионовый цикл у пшеницы, но существенно снижала активность АПО при тепловом стрессе, тогда как в условиях засухи и холодового стресса достоверно существенного снижения не обнаружено (41). Другие авторы сообщали, что засуха приводила к усилению активности связанных со стрессом генов $A P X 1, S A M S 1$ и HSP17.8 в листьях пшеницы и повышала активность ферментов аскорбат-глутатионового цикла, тогда как у растений, обработанных $B$. amyloliquefaciens 5113, количество транскриптов этих генов уменьшалось, что свидетельствует об улучшении состояния гомеостатических механизмов за счет бактериального прайминга (68). Очевидно, что разные штаммы Bacillus spp. могут по-разному снижать степень 
окислительных повреждений с вовлечением различных биохимических путей, что может зависеть от многих факторов, включая характеристику самого штамма, вид растения, тип стресса и его интенсивность. В целом во всех исследованиях отмечали улучшение состояния всей про-антиоксидантной системы в инокулированных бациллами растениях, что при засухе проявлялось в снижении содержания конечного продукта перекисного окисления липидов - МДА (13, 22, 28, 35, 52).

Регуляция уровня фитогормонов. Важным механизмом Bacillus-опосредованного повышения засухоустойчивости и урожайности растений $(16,23)$, в частности пшеницы $(13,68,70)$, служит продукция и(или) регуляция количества фитогормонов $(26,63,69,72)$ как центральных связующих звеньев, играющих ключевую роль в перепрограммировании онтогенетических и основных сигнальных каскадов, участвующих в формировании стрессоустойчивости растений.

Показано, что фильтраты жидких культур Bacillus spp. содержат фитогормоны - ауксины, цитокинины, гиббереллины, АБК, СК, ЖК $(71,72)$, играющие важную роль в фотосинтезе, росте растений и целостности плазматической мембраны, а также в развитии MIST (13, 73-75). Среди продуктов Bacillus spp. индольные соединения, например индолил3-уксусная кислота, играют жизненно важную роль в стимуляции роста и развитии растений, будучи основным ауксином, регулирующим деление и удлинение клеток, их разрастание и дифференциацию, развитие сосудистых тканей и апикальное доминирование $(13,16)$. Bacillus spp. используют для взаимодействия с растениями продуцируемую ИУК как элемент своей стратегии колонизации, включая фитостимуляцию и обход основных защитных механизмов растений. Многочисленные исследования показали, что продуцирующие ИУК бациллы значительно усиливают рост растений пшеницы как в норме, так и при засухе $(28,40,42,63)$, обусловливая повышение поглощения воды и питательных веществ. Увеличение площади поверхности и длины боковых и придаточных корней из-за высокой секреции бактериями ИУК играет жизненно важную роль в улучшении потребления и усвоения микро- и макроэлементов, в ускорении роста и формировании засухоустойчивости растений $(13,42,70,76)$. Согласно недавним исследованиям, Bacillus spp. контролируют уровень эндогенной ИУК в корнях растений, регулируя экспрессию ауксин-чувствительных генов и тем самым вызывая изменения в архитектуре корня (23). Засуха снижала содержание ИУК и вызывала активацию гена $A U X / I A A 1$ в неинокулированных проростках пшеницы, тогда как при инокуляции штаммом B. subtilis LDR2 coдержание ИУК увеличивалось (примерно на 80 \%), а экспрессия гена $A U X / I A A 1$ подавлялась (63). Эти данные предполагают, что B. subtilis модулирует ауксиновый сигнальный путь для защиты растений пшеницы от засухи. Выявлены биохимические пути и гены, контролирующие бактериальный синтез ИУК, при этом предполагается, что основным предшественником при образовании ИУК у микроорганизмов служит L-триптофан (77). Однако могут существовать и другие пути биосинтеза ИУК (индол-3-ацетамидный, индол-3-пируватный и триптаминовый), и иногда бактериальный штамм обладает более чем одним путем синтеза ИУК $(77,78)$. Считается, что наиболее широко способность продуцировать ИУК распространена среди почвенных бактерий (75) и чаще встречается среди эндофитных бактерий, чем среди эпифитных (77). Так, из исследованных 363 эпифитных и 373 эндофитных бактерий доля ИУК-продуцирующих эндофитов составляла $34 \%$, а эпифитов - $21 \%$ (79). Еще одна важная группа фитогормонов, 
продуцируемых Bacillus spp., - цитокинины, регулирующие прорастание семян, деление клеток в корнях и побегах растений, открытие устьиц, мобилизацию питательных веществ в условиях засухи $(23,28,31)$. Сообщается, что 90 \% Р-солюбилизирующих бактерий обладают способностью продуцировать цитокинины in vitro (23). Для многих штаммов Bacillus spp. детектирована способность к синтезу гиббереллинов, регулирующих различные физиологические процессы (прорастание семян, удлинение стебля, цветение, созревание плодов, а также старение листьев и плодов) $(35,80)$. Однако точный механизм, посредством которого гиббереллины способствуют росту растений при засухе, не совсем ясен. Предполагается, что усиление роста корней и увеличение плотности корневых волосков под влиянием продуцирующих гиббереллин бактерий связано с повышением потребления питательных веществ и воды растениями-хозяевами (69).

Наряду с повышением засухоустойчивости растений в результате микробной колонизации было зафиксировано изменение в содержании фитогормона АБК (42) - ключевого участника регуляции стрессовых реакций (69). Индуцированные бациллами сдвиги в количестве эндогенной АБК приводили к изменению архитектуры корневой системы за счет увеличения числа боковых корней и модификации водного статуса посредством регуляции гидравлической проводимости корней, уменьшения скорости транспирации листьев, повышения устьичной проводимости и индукции экспрессии генов, участвующих в обеспечении засухоустойчивости (42). Показано, что почти $2 / 3$ из 2000 индуцированных засухой генов регулируются АБК (81). Обработка штаммом B. subtilis LDR2 способствовала поддержанию фотосинтетической активности растений пшеницы в условиях засухи, при этом снижалось индуцируемое стрессом накопление АБК и АЦК (63). Так как ингибирование биосинтеза АБК подавляет экспрессию гена белка водного транспорта аквапорина TaAQP7, транскрипционная активность которого возрастает при водном стрессе, вызванное бактеризацией Bacillus снижение количества АБК свидетельствуют о том, что продукты бацилл модулируют засухоустойчивость растений посредством ап-регуляции гена $T a A Q P 7$. Вместе с тем проростки, обработанные LDR2, характеризовались усилением экспрессии гена TaCTR1, кодирующего ключевой негативный регулятор этиленовой сигнальной трансдукции, а также гена фактора транскрипции TaDREB2, который участвует в регуляции формирования устойчивости растений к широкому спектру абиотических стрессов (63). По мнению авторов (63), повышение засухоустойчивости пшеницы под влиянием B. subtilis LDR2 обусловлено увеличением содержания ИУК и уменьшением - АБК:АЦК, а также модулированием активности регуляторного компонента этиленового сигналинга CTR1 и транскрипционного фактора DREB2. Сообщалось, что B. velezensis 5113 может использовать передачу сигналов АБК для влияния на засухоустойчивость пшеницы $(41,43)$. В некоторых исследованиях при инокуляции бациллами в растениях одновременно со снижением количества АБК повышалось содержание СК и ЖК, выполняющих сигнальные функции (82). Продукция бактериями СК, ЖК и(или) регуляция их экзогенного уровня в растениях может играть важную роль в MIST, поскольку к настоящему моменту не вызывает сомнения ключевая роль этих фитогормонов в запуске сложной цепи защитных реакций, приводящих к формированию стрессоустойчивости растений $(42,69)$. Повышение накопления эндогенной СК в растениях пшеницы в ответ на инокуляцию B. subtilis 10-4 коррелировало с засухоустойчивостью растений, что указывает на вовлечение CK-зависимых сигнальных путей в реализацию 
эффектов, опосредованных B. subtilis $(28,34)$. Фитогормоны ЖК и этилен также играют важную регуляторную роль в сети взаимосвязанных сигнальных путей, участвующих в MIST $(42,69)$. Хотя в литературе есть сообщения об опосредованной бациллами активации СК-, ЖК- и этилен-зависимых сигнальных путей, вовлеченных у растений в развитие защитного ответа при биотических стрессах (83), сведений о регуляции бактериями засухоустойчивости пшеницы с участием этих сигнальных путей практически нет. Мы не обнаружили сообщений и о роли других фитогормонов (к примеру, брассиностероидов) в микроб-индуцированной системной устойчивости к засухе у растений пшеницы, хотя роль брассиностероидов в смягчении абиотических стрессов подтверждена (69).

Этилен - еще один важный для роста и развития растений гормон, регулирующий рост клеток, прорастание семян, старение листьев, созревание цветов и плодов, но эффект этилена зависит от его концентрации в тканях корня (69). Во время засухи биосинтез этилена усиливается, что отрицательно влияет на рост и развитие растений. В реакции разложения АЦК (непосредственного предшественника этилена) участвует АЦК-дезаминаза - ключевой фермент системы этилен-зависимой регуляции роста растений (52). Многие штаммы Bacillus spp. были зарегистрированы как продуценты АЦК-дезаминазы, и при их использовании отмечалось снижение индуцированного стрессом накопления этилена, который в противном случае мог бы стать ингибитором роста $(23,52)$. Использование бактериями АЦК в качестве источника питания приводит к уменьшению его содержания в растениях и, как следствие, к подавлению синтеза этилена в корнях. Предшественник этилена АЦК высвобождается из корней в ризосферу растения-хозяина и расщепляется секретируемой Bacillus spp. АЦК-дезаминазой до аммиака и $\alpha$-кетобутирата. В конечном итоге содержание этилена снижается, что, в свою очередь, способствует росту растений, так как при уменьшении концентрации этилена улучшается поглощение воды и питательных веществ (44-46, 50). Показана способность продуцирующих АЦК-дезаминазу PGPB, включая Bacillus spp., улучшать рост пшеницы во время засухи (35, 44-46). К примеру, в условиях засухи в растениях, инокулированных продуцирующими АЦК-дезаминазу бактериями B. amyloliquefaciens значительно повышалась интенсивность фотосинтеза, транспирация, устьичная проводимость, содержание хлорофиллов а и $\mathrm{b}$, а также урожайность зерна $(44,46)$. Согласно другим исследованиям, инокуляция бактериями, продуцирующими АЦК-дезаминазу, приводила к заметному увеличению относительного содержания воды в листьях пшеницы при водном стрессе (54).

Изучение влияния B. subtilis LDR2 на экспрессию гена, кодирующего CTR1 (регуляторный компонент этиленового сигнального пути, модулирующий связанные со стрессом изменения в растениях), показало, что при засухе в инокулированных LDR2 проростках пшеницы экспрессия TaCTR1 гена была выше, чем в неинокулированных, что свидетельствует о вовлечении этих бактерий в повышение засухоустойчивости пшеницы (63). Интересно, что, хотя активность АЦК-дезаминазы описана для многих штаммов Bacillus, гены АЦК-дезаминазы (структурный ген $\operatorname{acd} S$ и peгуляторный ген $a c d R$ ) не были идентифицированы в 271 штамме с полностью секвенированным геномом (23). Эти штаммы принадлежали к классу Bacilli и представляли многие почвенные и связанные с растениями виды родов Bacillus и Paenibacillus (23).

Биоконтроль фитопатогенов и продукция метаболитов. К не- 
прямым механизмам Bacillus-опосредованного улучшения роста растений пшеницы при засухе относится эффективная конкуренция и подавление патогенных микроорганизмов (грибов, бактерий) с помощью продуцируемых вторичных метаболитов с антибиотическими свойствами, включая рибосомные (бактериоцины) или нерибосомные (липопептиды, поликетиды) пептиды с низкой молекулярной массой, ферментов, разрушающих клеточную стенку фитопатогенов (хитиназы, целлюлазы, глюканазы, протеазы, липазы), сидерофоров, летучих органических соединений, а также благодаря снижению образования этилена в растениях и активации MIST против стрессов (23) (см. рис.). Для разных видов Bacillus, включая B. subtilis, B. amyloliquefaciens, B. cereus, B. thuringiensis и B. coagulans, показана способность синтезировать бактериоцины и бактериоциноподобные вещества (амилолизин, амизин, субтилин, субтилозин А, субтилозин В, турицин) с антимикробными свойствами в отношении фитопатогенов. Однако гораздо более сильные антимикробные свойства проявляют бациллы, продуцирующие нерибосомные липопептиды и пептиды (23). Недавние исследования показали, что липопептиды также влияют на колонизацию и coхранение представителей видов Bacillus в ризосфере, что стимулирует защитные механизмы растений (23). Наиболее важные продуцируемые бациллами циклические липопептиды представлены семействами сурфактина, итурина и фенгицина. Показано, что B. subtilis, B. amyloliquefaciens, B. licheniformis, B. pumilus и B. coagulans синтезируют липопептиды семейства сурфактинов (сурфактин, лихенизин, пумилацидин, галобацилин, бамилоцин) - гептапептидов, которые действуют как противогрибные и антибактериальные средства. Семейство итуринов состоит из гептапептидов (итурин, микосубтилин, бацилломицин, бациллопептины, миксирин, моявенсин, субтулен, продуцируемые B. subtilis, B. amyloliquefaciens, B. circans, B. pumilus и $B$. vallismortis), обладающих ингибирующим действием против широкого спектра грибов, но менее активных против бактерий. Продукцию липопептидов семейства фенгицинов (декапептиды фенгицин, плипастатин, мальтацин), полезных для защиты растений от грибных патогенов, обнаружили у B. subtilis и B. amyloliquefaciens (23). Нерибосомные липопептиды включают курстакины, бацитрацины, полимиксины, грамицидины и тирокидины. Курстакины - циклические или линейные гептапептиды, специфичные для B. cereus и B. thuringiensis, обладают способностью дестабилизировать биологические мембраны как бактерий, так и грибов. Бацитрацины - циклические декапептиды, продуцируемые B. licheniformis, B. subtilis и B. sonorensis, активность которых в первую очередь направлена против грамположительных бактерий. Полимиксины - циклические декапептиды, продуцируемые Paenibacillus polymyxa, которые подавляют рост и размножение грамотрицательных бактерий. Грамицидины и тироцидины - циклические декапептиды, синтезируемые B. brevis, активны в отношении широкого спектра грамотрицательных и грамположительных бактерий. Некоторые виды бацилл продуцируют и другие нерибосомные пептиды (бацилизин, ризоктицин, амикумацин, микобациллин, дикетопиперазины) и поликетиды (бациллин, дигидробациллин, диффицидин, макролактин) с различными противогрибными и антибактериальными свойствами. У наиболее часто используемых биоагентов B. subtilis и B. amyloliquefaciens значительная часть генетического материала (соответственно 4-5 \% и 8,5 \%) отвечает за синтез вторичных метаболитов с потенциалом для продукции более 20 антимикробных соединений разной структуры. В настоящее время кластеры генов, кодирующих бактериоци- 
ны, а также пептиды и поликетиды легко идентифицируются при геномном сканировании. Для 328 штаммов 57 видов порядка Bacillales идентифицированы в общей сложности 583 предполагаемых кластера генов бактериоцина, кроме того, у 49 видов Bacillales обнаружили 1231 предполагаемый кластер генов нерибосомных антимикробных соединений, которые объединили в группы в соответствии с 23 типами пептидов и пятью типами вторичных метаболитов поликетидной природы (23). Во многих исследованиях показано, что гидролитические ферменты (хитиназы, хитозаназы, глюканазы, целлюлазы, липазы и протеазы), синтезируемые бациллами, очень активно разрушают клеточные стенки грибов и бактерий, а также повышают устойчивость растений к стрессам $(13,23,84)$. Описано значение синтезируемых бациллами сидерофоров в биоконтроле, основанном на конкуренции за Fе с целью уменьшения его доступности для патогенов (23). Большинство бактериальных сидерофоров представляют собой катехолаты, такие как бациллибактин, продуцируемый некоторыми бациллами (например, B. subtilis, B. amyloliquefaciens, B. cereus, B. thuringiensis). Кроме того, представители рода Bacillus продуцируют широкий спектр сидерофоров, в частности пиовердин, пиохелин, шизокинен, петробактин (23).

Bacillus spp. также секретирует внеклеточные полисахариды и различные летучие органические соединения, которые изменяют структуру и морфологию корней и вызывают MIST у растений (85) (см. рис.). Летучие органические соединения имеют липофильную природу и действуют как сигнальные молекулы для меж- и внутриорганных коммуникаций и передачи сигналов от клетки к клетке. Инокуляция $B$. amyloliquefaciens IN937а и $B$. subtilis GB03 индуцировала продукцию летучих органических соединений 2R,3R-бутандиола и 3-гидрокси-2-бутанона в растениях арабидопсиса, что модулировало экспрессию генов, ответственных за рост растений. Колонизация корней арабидопсиса штаммом Pseudomonas chlororaphis O6 индуцировала продукцию 2R,3R-бутандиола, что приводило к закрытию устьиц и повышению засухоустойчивости растений; также была установлена роль различных фитогормонов (СК, этилен и ЖК) в модуляции засухоустойчивости. Однако в проростках пшеницы, обработанных B. thuringiensis AZP2, увеличение биомассы и повышение выживаемости растений во время засухи происходили, напротив, из-за снижения выбросов летучих органических соединений, а также усиления фотосинтеза $(35,40)$.

Появление новых методов исследований позволяет более широко и комплексно оценить влияние микробных инокуляций на все жизненно важные системы растений, вовлеченные в регуляцию роста и развития как в норме, так и в стрессовых условиях. Благодаря метаболомным исследованиям обнаружено, что в норме инокулированные штаммом B. velezensis 5113 и неинокулированные растения пшеницы значительно различались по накоплению 61 метаболита: для 36 оно увеличивалось, для 25 - уменьшалось (41). В частности, инокуляция B. velezensis 5113 повышала содержание аминокислот L-пролина и L-глутамина, $\gamma$-аминомасляной кислоты (ГАMK), существенно влияла на метаболизм аланина, аспартата, глутамата и биосинтез флавоноидов (41), участвующих в защитных реакциях у растений и во взаимодействиях между растениями и микробами. Засуха вызывала значительное накопление метаболитов (обнаружили 194 метаболита) в листьях неинокулированных проростков пшеницы по сравнению с контрольными проростками, которые не были бактеризованы и не подвергались стрессу. 
У инокулированных B. velezensis 5113 растений засуха вызывала накопление только 139 метаболитов. При этом в условиях засухи значительную разницу между инокулированными и неинокулированными растениями пшеницы отмечали только по 29 метаболитам (содержание 10 увеличились, 19 уменьшились) (41). В частности, обработка B. velezensis 5113 снизила накопление некоторых метаболитов, связанных с биосинтезом флавонов и флавонолов, а также интенсивность биосинтеза флавоноидов в листьях у не подвергнутых и подвергнутых стрессу проростков пшеницы, что указывает на возможное ингибирующее действие B. velezensis 5113 на биосинтез флавоноидов в растениях (41). Эти же авторы с использованием протеомного анализа показали, что при обработке B. velezensis 5113 в листьях пшеницы увеличивалось содержание белков, которые участвуют в процессе фотосинтеза (41). Интересно, что образование этих белков подавлялось во всех неинокулированных растениях в условиях засухи, что указывает на важную роль $B$. velezensis 5113 в защите процесса фотосинтеза у подвергнутых засухе растений пшеницы. Также было обнаружено, что в ответ на обработку B. velezensis 5113 в листьях пшеницы активируется синтез нескольких белков с неизвестными функциями. Особого внимания заслуживает тот факт, что в растениях пшеницы, инокулированных B. velezensis 5113, значительно повышалось количество ГАМК, глутамина и пролина. Роль пролина и глутамина при Bacillus-опосредованной регуляции засухоустойчивости пшеницы уже описывалась в литературе (34), но для ГАМК такие работы отсутствуют. Имеются единичные сведения об участии ГАМК в становлении микробнорастительных взаимодействий (86). В частности, сообщалось, что ГАМК синтезируется внутри клубеньков бобовых и участвует в формировании симбиоза между бактериями и растением. При дефиците влаги под влиянием обработки эндофитной бактерией $B$. subtilis В26 в побегах и корнях тимофеевки усиливалось накопление ГАМК и повышалась засухоустойчивость растений (87). Небелковая аминокислота ГАМК, которая быстро накапливается в тканях растений в ответ на биотические и абиотические стрессы, играет значительную роль в адаптации растений к стрессам и участвует в регуляции физиологических и биохимических путей, обеспечивающих устойчивость растений к стрессам, включая дефицит воды (78). ГАМК связана с поддержанием углеродно-азотного баланса, с метаболизмом аминокислот, углеводов и регуляцией роста (86). Кроме того, ГАМК может действовать как эффективный осмолит, не обладающий токсическими эффектами, и как улавливатель АФК у растений, подвергшихся абиотическому стрессу. Следует отметить, что сравнительно недавно ГАМК начали рассматривать как вторичный метаболит и сигнальную молекулу, вовлеченную в сигналинг и защитные механизмы у растений (86). Выявленная способность B. velezensis 5113 модулировать содержание ГАМК в нестрессированных листьях пшеницы может указывать на то, что этот штамм способен влиять на устойчивость растений к засухе посредством праймирования аналогично тому, как это происходит при применении экзогенного ГАМК (41). Вероятно, при стрессе вызванное бактеризацией накопление ГАМК в тканях растений способствует повышению их устойчивости, обеспечивая формирование критического звена в каскаде реакций от восприятия сигнала стресса до последовательных физиологических ответов. Это свидетельствует в пользу важной роли этого метаболита в индуцированной бациллами устойчивости пшеницы к засухе, что, безусловно, заслуживает пристального внимания и дальнейших исследований. 
Засухотолерантные штаммы Bacillus spp. и их эффективность. Особое внимание уделяется выделению засухотолерантных ростостимулирующих штаммов Bacillus spp. из ризосферы растений, обитающих в условиях дефицита влаги, поскольку от роста и выживания бактерий в таких условиях зависит их способность смягчать повреждающее действие засухи на растения $(50,52)$. Недавние исследования U. Rashid с соавт. (52) показали, что засухотолерантные штаммы $B$. megaterium MU2 и $B$. licheniformis MU8 из ризосферы растений, произрастающих на засушливых и полузасушливых территориях, вызывают системную устойчивость пшеницы к засухе. В эксперименте in vitro авторы изучили 90 изолятов ризобактерий, из которых 38, как оказалось, проявляли одно или несколько PGP свойств, включая солюбилизацию Р, К и продукцию экзополисахаридов, но только два штамма - B. megaterium MU2 и B. licheniformis MU8 обладали лучшим потенциалом для повышения засухоустойчивости растений (активность АЦК-дезаминазы, продукция ИУК и антагонистическая активность против фитопатогенов). Кроме того, при воздействии засухи (-0,73 МПа) у B. megaterium выявили продукцию трех новых полипептидов с молекулярной массой 18 кДа, 35 кДа и 30 кДа (52). Два отобранных засухотолерантных штамма в условиях нормального орошения и засухи увеличивали всхожесть семян пшеницы соответственно на 11-46 \%, жизнеспособность проростков - на 11-151\%, накопление сырой массы - на 35-192 \%, сухой на 58-226 \%. Более того, эти штаммы эффективно колонизировали корни пшеницы и увеличивали относительное содержание воды, количество фотосинтетических пигментов и осмолитов. Так, после воздействия засухи выживаемость растений пшеницы, инокулированных B. megaterium MU2, повысилась благодаря увеличению относительного содержания воды (на $59 \%$ ), количества хлорофиллов а, b и каротиноидов (соответственно на 260, 174 и 70 \%), содержания белка (на $136 \%$ ), пролина (на $117 \%$ ) и снижения образования МДА (на 57 \%) (52).

Генотипическая специфичность действия Bacillus spp. на растения пшеницы. На практике эффективность штаммов Bacillus spp. может варьировать в зависимости как от условий среды, так и от многих других факторов, включая генотип растений, их эколого-географическое происхождение, сортовые особенности, характеристики штаммов $(34,54$, 55, 88). Применение представителей Bacillus spp. для повышения урожайности полевых и овощных культур ограничивается вариативностью результатов, полученных в лаборатории, в теплице и в полевых условиях (23). Фактически при повторной интродукции (при инокуляции как растений, так и почвы) только у 1-2 \% PGPB положительное влияние на рост растений сопоставимо с результатами лабораторных тестов (23). Анализ многолетних данных об эффективности коммерческого биопрепарата Фитоспорин-М (основа B. subtilis 26Д, ООО НВП «БашИнком», г. Уфа, Россия) в полевых условиях на яровой пшенице показал более высокую отзывчивость на обработку семян биопрепаратом в засушливых условиях Оренбургской и Курганской областей (прибавка соответственно до 43 и 24 \%) (55). Выявлена специфичность взаимодействия Фитоспорина-М с разными генотипами пшеницы в зависимости от их устойчивости к засухе и принадлежности к экотипам. Наибольшую эффективность Фитоспорина-М отмечали в засушливых условиях на сортах яровой пшеницы степного экотипа (55). Результаты лабораторных экспериментов также показали, что в одинаковых условиях произрастания сорта пшеницы, принадлежащие к 
разным экотипам, проявляли неодинаковую засухоустойчивость при инокуляции B. subtilis 26Д (88). Штамм B. subtilis 26Д увеличивал всхожесть семян пшеницы сорта Саратовская 55 (степной волжский экотип) при засухе, тогда как практически не оказывал влияния или даже ингибировал всхожесть семян сорта Омская 35 (лесостепной западносибирский экотип) (88). К подобным результатам привела инокуляция штаммом B. subtilis 10-4, которая существенно смягчала повреждающее влияние засухи на всхожесть семян и рост растений (длина корней и побегов, сырая и сухая масса) у пшеницы устойчивого сорта Экада 70 (степной волжский экотип) на ранних стадиях онтогенеза и не оказала защитного эффекта по этим же показателям в отношении восприимчивого сорта Салават Юлаев (лесостепной западносибирский экотип) (34). Тем не менее обработка B. subtilis 10-4 индуцировала (хоть и в разной степени) защитные ответы на уровне клеток у обоих сортов, что проявлялось в снижении степени окислительного и осмотического повреждения клеток, вызываемого засухой, и в модулировании фотосинтеза и водного обмена (34). Другие авторы сообщали, что ростовая реакция пшеницы на инокуляцию бактериями, продуцирующими АЦК-дезаминазу, в норме и при засухе зависела от генотипа растения (46). Было высказано предположение о связи таких различий либо с составом корневых экссудатов, уникальным для определенных генотипов пшеницы, либо с иными различиями между генотипами, влияющими на их способность сохранять относительно высокую численность продуцентов АЦК-дезаминазы в ризосфере, что требует дальнейшего изучения. Выявление особенностей и различий между генотипами и экотипами пшеницы в реакциях на инокуляцию Bacillus spp. может привести к инновационным стратегиям отбора для улучшения засухоустойчивости растений. Успешное применение Bacillus spp. в полевых условиях во многом зависит от взаимодействия между растениями и бациллами, которое может быть ограничено плохой колонизацией ризосферы (23). Бациллам требуется 24 ч для образования биопленки, которая способствует колонизации корней и продлевает благотворное воздействие штаммов Bacillus на почву. Однако колонизация корней местными (аборигенными) штаммами бацилл более эффективна, чем лабораторными или коммерческими. Новые стратегии, например инженерия микробиома и селекционная оптимизация микроорганизмов, помогают обнаружить, модулировать и улучшать целевые признаки, повышая таким образом эффективность штаммов Bacillus spp. и препаратов на их основе. Необходимо понимать, как разные штаммы регулируют рост и развитие растений, учитывая при этом многочисленные факторы, влияющие на эффективность Bacillus spp., четко определять особенности и способ выбора наиболее эффективных штаммов. Транскриптомный анализ генома B. amyloliquefaciens выявил многочисленные гены, вовлеченные в обеспечение приживления бактерий в ризосфере и контроль полезных для растений признаков, включая использование полисахаридов растений, подвижность клеток и хемотаксис, вторичный синтез антибиотиков и кластеры, относящиеся к стимуляции роста растений (23). Показано, что экссудаты корней и семян служат индукторами генов, продукты которых участвуют в колонизации корней и взаимодействиях растений с бациллами $(49,89,90)$. Новые исследования взаимодействия растений и бактерий раскрывают способность растений формировать свою ризосферу и микробиом эндоризы (91). Полученные к настоящему времени результа- 
ты указывают на существование других не известных пока механизмов Bacillus-опосредованной засухоустойчивости у пшеницы, которые будут раскрыты с развитием технологий анализа функций генов (41). Использование методов секвенирования следующего поколения (Next Generation Sequencing, NGS) в сочетании с протеомикой, метагеномикой, метаболомикой помогут уточнить детали этих взаимодействий, в том числе то, каким образом такая взаимосвязь влияет на рост и засухоустойчивость растений $(23,90)$.

Применение композиций Bacillus spp. с другими биорегуляторами и микроорганизмами. В целях повышения эффективности $B a$ cillus spp. вызывает интерес составление их различных комбинаций с другими регуляторами роста, а также консорциумов с другими потенциально полезными микроорганизмами. К примеру, продуцирующие АЦК-дезаминазу бактерии B. amyloliquefaciens в сочетании с органическим биоудобрением биочаром (древесным биоуглем) эффективнее смягчали воздействие мягкой и сильной полевой засухи на растения пшеницы, усиливали их рост и повышали урожайность по сравнению с применением B. amyloliquefaciens или биочара по отдельности (44). Эти результаты подтвердили данные, полученные авторами ранее в лабораторных условиях, где применение $B$. amyloliquefaciens улучшало морфологические показатели пшеницы в условиях индуцированной полиэтиленгликолем засухи $(45,46)$. В других исследованиях инокуляция $B$. subtilis 10-4 в комбинации с CK также более эффективно защищала растения пшеницы от засухи и комбинированного воздействия засухи и фузариозной корневой гнили, что проявилось в заметном улучшении показателей роста (длина корней и побегов, накопление их сырой и сухой биомассы), в модуляции процессов фотосинтеза, водного обмена, снижении степени окислительных и осмотических повреждений (22). Схожий положительный эффект комбинации PGPB + CK на растения пшеницы при недостатке воды получили N. Khan и A. Bano (50). При засухе растения пшеницы (устойчивый и восприимчивый к засухе сорта), обработанные композицией PGPB (B. cereus P2, Planomicrobium chinense P1) + CK, характеризовались значительным увеличением количества белков и сахаров в листьях, содержания хлорофилла и интенсивности его флуоресценции, а также меньшим синтезом индуцированного стрессом пролина, антиоксидантных ферментов и снижением перекисного окисления липидов в сравнении с контрольными неинокулированными растениями и растениями, инокулированными только PGPB (50). Использование комбинации штаммов PGPB Bacillus spp. и CK представляется многообещающей и экологически безопасной стратегией снижения повреждающего действия засухи на растения пшеницы. Некоторые авторы сообщали о перспективности применения PGPB в сочетании с экзополисахаридами для борьбы со стрессами, вызываемыми засухой (67). Исследование Y. Li с соавт. (92) показало, что добавление супервпитывающего полимера (СВП) к культуре Bacillus sp. L56SAP значительно увеличивало выживаемость инокулянта и способствовало смягчению последствий засухи для пшеницы (улучшению прорастания семян и роста растений) и повышению плодородия почвы (активность уреазы, сахарозы и дегидрогеназы). Кроме того, препарат Bacillus sp. L-56 + CBП значительно повышал содержание хлорофилла в растениях пшеницы. Анализ методом qPCR в реальном времени показал, что при обработке Bacillus sp. L-56 + CBП у растений пшеницы в условиях засухи значительно снижаются уровни экспрессии генов, участвующих в улавливании АФК (TaCAT, $C s C A T, T a A P X$ и $C s A P X 2)$, биосинтезе этилена 
(TaACO2, CsACO1 и CsACS1), CK (TaPR1-1a и CsPR1-1a), реакции на стресс (TaDHN3, TaLEA и CSLEA11), но активируется транскрипция генов TaNAC2D и CsNAC35 (92). Некоторые исследователи сообщали об эффективности применения B. subtilis CP4, выделенного из почвы, в сочетании с грибами арбускулярной микоризы для увеличения накопления $\mathrm{N}, \mathrm{P}, \mathrm{Cu}, \mathrm{Fe}$ и $\mathrm{Zn}$ в зерне пшеницы, что приводило как к биофортификации зерновой продукции, так и к усилению роста, повышению фотосинтетической активности, урожайности и продукции метаболитов у растений пшеницы в полевых условиях (65). Кроме того, послеуборочный физико-химический анализ образцов почвы показал, что при внесении B. subtilis CP4 и грибов арбускулярной микоризы ферментативный статус почвы (активность инвертазы, $\beta$ глюкозидазы, дегидрогеназы) улучшался по сравнению с необработанными участками, при этом именно совместное применение PGPB и грибов в наибольшей степени способствовало повышению почвенного плодородия (65). Сообщалось об экспериментах по изучению влияния консорциумов Bacillus spp. с другими PGPB на рост и урожайность пшеницы как в лабораторных, так и в полевых условиях $(39,93)$. Так, обработка тетракомбинацией B. megaterium + Arthrobacter chlorophenolicus + Enterobacter $\mathrm{sp} .+$ Pseudomonas aeruginosa значительно увеличивала высоту растений пшеницы (в теплице и в полевом опыте соответственно на 24,56 и 47,06 \%), урожайность зерна (на 75,80 и 40,09 \%) и соломы (на 76,55 и 42,63 \%) по сравнению с контролем. Та же четырехкомпонентная и две трехкомпонентные инокуляции - B. megaterium + A. chlorophenolicus $+P$. aeruginosa и A. chlorophenolicus + Enterobacter spp. $+P$. aeruginosa способствовали увеличению урожая и усвоению питательных веществ пшеницей (39). Сообщалось, что инокуляция штаммом $B$. megaterium М3 и комбинацией бактерий (B. megaterium M3 + B. subtilis 05U142 + A. brasilense Sp245) создавала бо́льшую обеспеченность растений пшеницы питательными элементами, чем внесение минеральных удобрений (93). Подобные сравнения с химически удобренными почвами приводятся и в других работах $(26,37,94)$. Следует обратить внимание на то, что некоторые PGPB при инокуляции способны отрицательно влиять на мутуалистические ассоциации между растениями и аборигенными почвенными микроорганизмами, и это может быть причиной отсутствие благоприятного эффекта у некоторых PGPB (95). Структура сообщества ризобактерий пшеницы очень динамична и зависит от различных факторов: сорта, возраста растения, стадии роста, расстояния частиц почвы от волосков корня, характера корневой экссудации, свойств почвы и агротехнических приемов $(26,90)$. В целом накопленные данные свидетельствуют о перспективности сочетаний Bacillus spp. с другими природными регуляторами роста и различными микроорганизмами для усиления ростостимулирующего и антистрессового воздействия микробиологических препаратов на растения и повышения почвенного плодородия.

Коммерциализация бациллярных биопрепаратов. Многие полезные штаммы Bacillus spp. коммерчески доступны для применения в качестве биоудобрений и средств защиты растений в виде готовых препаратов (табл.).

Примеры коммерческих биопрепаратов на основе Bacillus spp. для стимуляции роста и защиты растений, включая пшеницу

\begin{tabular}{l|l|l}
\hline \multicolumn{1}{c|}{ Основа } & \multicolumn{1}{c}{ Название биопрепарата } & \multicolumn{1}{c}{ Производитель } \\
\hline B. subtilis 26Д & Фитоспорин-M & «НВП БашИнком», Россия \\
B. subtilis GB03 & Quantum-400 & «Ecological Laboratories, Inc.», США \\
B. subtilis QST713 & Serenade & «AgraQuest, Inc., США \\
B. subtilis улуч. GB03 & Alinit, Kodiak & «Gustafson, Inc»., США
\end{tabular}


B. subtilis MBI600

B. subtilis Ч-13

B. subtilis $63-\mathrm{Z}$

B. subtilis ИПМ 215

B. subtilis В-10 ВИЗР

B. subtilis $\mathrm{M}-22$ ВИЗР

B. subtilis BKM-B-2604D,

B. subtilis BKM-B-2605D

B. subtilis

B. subtilis

B. subtilis

B. velezensis $\mathrm{ABi} 19$

B. subtilis

B. subtilis

B. subtilis

B. amyloliquefaciens

B. amyloliquefaciens,

B. velezensis $\mathrm{FZB} 42$

B. velezensis $\mathrm{FZB} 45$

B. atrophaeus Abi05

B. pumilus

B. pumilus

B. pumilus

B. licheniformis

B. velezensis

B. megaterium

Bacillus sp.

Bacillus spp.
Subtilex

БисолбиСан

Баксис

Бактофит

Алирин-Б

Гамаир

Витаплан

Companion

Cease

Pro-Mix

FZB24

Bio Safe

Ecoshot

Biosubtilin

BioYield

Rhizocell GC

RhizoVital ${ }^{\circledR} 42$

RhizoVital@45

RhizoFert ${ }^{\circledR}$

Yield Shield

Ballad Plus

Sonata

EcoGuard $\AA$

Botrybel

Symbion-P

Sublic

Bacillus SPP
Продолжение таблиць

«Becker Underwood, Inc.», США

ВНИИСХМ, Россия

«Инвиво», Россия

«Сиббиофарм», Россия

«АгроБиоТехнология», Россия

«АгроБиоТехнология», Россия

ВИЗР, Россия

«Growth Products, Ltd.», США

«BioWorks, Inc.», США

«Premier Horticulture, Inc.», Канада

«ABiTEP GmbH», Германия

«Lab. Biocontrole Farroupilha», Бразилия

«Kumiai Chemical Industry», Япония

«Biotech International, Ltd.», Индия

«Gustafson, Inc.», США

«Lallemand Plant Care», Франция

«ABiTEP GmbH», Германия

«ABiTEP GmbH», Германия

«ABiTEP GmbH», Германия

«Bayer CropScience», CША

«AgraQuest, Inc.», CША

«AgraQuest, Inc.», США

«Novozymes A/S», Дания

«Agricaldes», Испания

«T. Stanes \& Co., Ltd.», Индия

«ELEP Biotechnologies», Италия

«Bio Insumos Nativa», Чили

В мире происходит ежегодный рост числа разработок новых коммерческих препаратов, содержащих полезные штаммы бацилл - B. subtilis, B. megaterium, B. amyloliquefaciens, B. licheniformis, B. pumilus, B. cereus, B. thuringiensis, B. velezensis (23). Во многих работах уделяется внимание отдельным этапам коммерциализации: выделению штаммов бактерий с полезными свойствами, скринингу, методам ферментации, массовому производству, определению жизнеспособности рецептуры, токсикологии, производственным отношениям, контролю качества и эффективности практического применения (13). На успех коммерциализации полезных штаммов влияет рыночный спрос и популяризация препаратов, их безопасность, стабильность, длительность хранения, малозатратноть и простота применения, наличие материалов-носителей (96). Один из наиважнейших аспектов разработки и коммерциализации эффективных биопрепаратов на основе бацилл - знание механизмов их взаимодействия с растениями в норме и особенно при стрессе. Кроме того, результат разработок во многом зависит от эффективности взаимодействия между научными организациями и отраслями промышленности.

Итак, обобщение данных литературы указывает на важную роль Bacillus spp. в регуляции роста, развития и стрессоустойчивости растений, что, несомненно, расширяет значимость практического применения бацилл для повышения засухоустойчивости и урожайности важнейших сельскохозяйственных культур, включая пшеницу. Об этом также свидетельствует ежегодное увеличение числа фундаментальных исследований, разработок и объемы распространения коммерческих бациллярных биопрепаратов. Вместе с тем полученные к настоящему времени результаты указывают на наличие пока что не раскрытых механизмов Bacillus-опосредованной засухоустойчивости пшеницы. В будущих исследованиях представляется важным сосредоточить внимание на метаболических путях, обеспечивающих индуцированную бациллами системную устойчивостью растений, на расширении знаний о спектре продуцируемых бациллами метаболитов, сигнальных 
молекул (фитогормонов, аминокислот и др.) и их вкладе в функционирование жизненно важных систем защиты растений, а также на выявлении новых ключевых компонентов, ответственных за регуляцию засухоустойчивости пшеницы бактериями. Для более полной оценки и использования потенциала бактерий Bacillus spp. в качестве инокулянтов, обеспечивающих устойчивую продуктивность пшеницы, необходимо понимать, каким образом разные штаммы стимулируют рост и защищают растения от стрессов, и четко определять факторы, способствующие более эффективному практическому использованию этих штаммов, особенно в засушливых условиях меняющегося климата. Особого внимания заслуживает изучение специфичности взаимодействия бациллярных штаммов с разными сортами пшеницы и прецизионный подбор их комплементарных сочетаний с учетом географических факторов произрастания растений (климат, почва). Также важно выявлять наиболее эффективные сочетания Bacillus spp. с другими природными регуляторами роста и микроорганизмами (мультиштаммовые консорциумы), проявляющие аддитивное действие при защите пшеницы от засухи и предназначенные для адресного применения в различных почвенно-климатических условиях возделывания культуры. Кроме того, будущие исследования должны быть сосредоточены на разработке приемов сохранения способности бациллярных штаммов и(или) их комбинаций (консорциумов) с другими регуляторами роста и микроорганизмами влиять на рост и засухоустойчивость растений пшеницы в полевых условиях так же эффективно, как в лабораторных тестах. Углубленное изучение механизмов взаимодействий бацилл с растениями пшеницы при засухе основывается на интеграции современных подходов (методы NGS, протеомики, метагеномики и метаболомики) с целью разработки перспективных проектов и стратегий практического применения эффективных и экологически безопасных микробиологических препаратов.

Институт биохимии и генетики -

Поступила в редакцию

обособленное структурное подразделение

7 апреля 2021 года

Уфимского федерального исследовательского иентра РАН,

450054 Россия, г. Уфа, пр. Октября, 71,

e-mail: oksanaibg@gmail.com

Sel'skokhozyaistvennaya biologiya [Agricultural Biology], 2021, V. 56, № 5, pp. 843-867

\section{ADAPTATION AND TOLERANCE OF WHEAT PLANTS TO DROUGHT MEDIATED BY NATURAL GROWTH REGULATORS Bacillus spp.: MECHANISMS AND PRACTICAL IMPORTANCE (review) \\ O.V. Lastochkina ${ }^{凶}$}

Institute of Biochemistry and Genetics - Subdivision of the Ufa Federal Research Center RAS, 71, pr. Oktyabrya, Ufa, Russia 450054, e-mail oksanaibg@gmail.com ( $₫$ corresponding author) ORCID:

Lastochkina O.V. orcid.org/0000-0003-3398-1493

The author declares no conflict of interests

Acknowledgements:

Supported financially from the Russian Foundation for Basic Research, the Project No. 20-116-50151

Received April 7, 2021 doi: 10.15389/agrobiology.2021.5.843eng

Abstract

Environmental abiotic factors leading to water deficiency significantly limit the production of major crops worldwide (Z. Ahmad et al., 2018). In the face of rapid population growth and climate change, it is important to ensure food security, which is mainly possible by increasing the productivity of strategically important crops, including wheat, which is used for human consumption in many 
regions of the world and provides more than $50 \%$ of food energy needs (S. Asseng et al., 2019). Application of beneficial growth-stimulating bacteria Bacillus spp. are effective, environmentally friendly and safe natural strategy for protecting plants from stresses resulting in water deficiency (M. Kaushal et al., 2019; A. Hussain et al., 2020; M. Camaille et al., 2021). To date, the growthstimulating and protective effect of Bacillus spp. under various abiotic stresses are indicated for a wide range of plants (S. Moon et al., 2017; H.G. Gowtham et al., 2020; N. Shobana et al., 2020), including wheat (G. Sood et al., 2020; U. Rashid et al., 2021). The mechanisms of this physiological action of Bacillus spp. on host plants remain largely unknown. Presumably, it is due to i) competition for space and nutrients with plant pathogens and increased availability of macro- and micronutrients (S. Danish et al., 2019; D. Miljakovic et al., 2020; A. Kumar et al., 2021), ii) production of a wide range of bioactive components and protective compounds (M. Saha et al., 2016; R. Çakmakçı et al., 2017; N. Ilyas et al., 2020), and iii) induction of plant systemic tolerance to stresses (I.A. Abd El-Daim et al., 2019; C. Blake et al., 2021; U. Rashid et al., 2021). The efficacy of the same Bacillus strain may vary, depending on many factors including a spectrum of the synthesized compounds, strains, plant species, ecological and geographical origin, varietal characteristics, the types of stresses during the growing season, etc. (A. Khalid et al., 2004; G. Salem et al., 2018; O. Lastochkina et al., 2020). This review summarizes an information on the current state of research and the latest available information on plant-microbe interactions with a focus on protecting wheat against drought. In particular, the mechanisms underlying Bacillus-mediated adaptation and tolerance of wheat plants to drought are under consideration. It is shown that Bacillus spp. can induce wheat drought tolerance due to i) synthesis of compounds which provide protection against osmotic and oxidative stresses (D. Miljakovic et al., 2020; R. Çakmakçı et al., 2017), ii) intracellular transmission and enhancement of protective signals by a cascade of mediators, iii) regulation of the protective protein gene expression and interorgan transduction with the participation of the main phytohormones, their biosynthesis in the whole plant (U. Rashid et al., 2021), and iv) numerous compounds involved in increasing the bioavailability of macro- and microelements and productivity (A. Hussain et al., 2020; A. Kumar et al., 2021). Bacillus spp. can positively influence plant photosynthesis and water exchange (I.A. Abd El-Daim et al., 2019), as well as drought tolerance of wheat genotypes of different agroecological groups (L.I. Pusenkova et al., 2020). The joint use of Bacillus bacteria with other natural growth regulators enhance their effectiveness and stability of action (M. Zafar-ul-Hye et al., 2019). The listed commercial bacillary biologicals are effective on wheats. The review contributes to the understanding of the fundamental mechanisms of wheat-Bacillus spp. interactions under drought, the development of Bacillus-based biologicals and their use in ecologically oriented technologies for wheat growing under changing climate conditions.

Keywords: plant growth-stimulating bacteria, Bacillus spp., wheat, drought, defense mechanisms, plant-microbe interactions, induced systemic tolerance.

\section{REFERENCES}

1. FAO. The state of food and agriculture. Climate change, agriculture and food security, 2016. Available: http://www.fao.org/3/a-i6030e.pdf. No date.

2. FAO. Cereal supply and demand brief, 2021. Available: http://www.fao.org/worldfoodsituation/csdb/ru/. No date.

3. Di Benedetto N.A., Corbo M.R., Campaniello D., Cataldi M.P., Bevilacqua A., Sinigaglia M., Flagella Z. The role of plant growth promoting bacteria in improving nitrogen use efficiency for sustainable crop production: a focus on wheat. AIMS Microbiology, 2017, 3(3): 413-434 (doi: 10.3934/microbiol.2017.3.413).

4. Ahmad Z., Waraich E.A., Akhtar S., Anjum S., Ahmad T., Mahboob W., Hafeez O.B.A., Tapera T., Labuschagne M., Rizwan M. Physiological responses of wheat to drought stress and its mitigation approaches. Acta Physiologiae Plantarum, 2018, 40: 80 (doi: 10.1007/s11738-018-2651-6).

5. Cramer G.R., Urano K., Delrot S., Pezzotti M., Shinozaki K. Effects of abiotic stress on plants: a systems biology perspective. BMC Plant Biology, 2011, 11: 163 (doi: 10.1186/1471-2229-11-163).

6. Farooq M., Wahid A., Kobayashi N., Fujita D., Basra S.M.A. Plant drought stress: effects, mechanisms and management. Agronomy Sustainable Development, 2009, 29: 185-212 (doi: 10.1051/agro:2008021).

7. Asseng S., Martre P., Maiorano A., Rötter R.P., O’Leary G.J., Fitzgerald G.J., Girousse C., Motzo R., Giunta F., Ali Babar M., Reynolds M.P., Kheir A.M.S., Thorburn P.J., Waha K., Ruane A.C., Aggarwal P.K., Ahmed M., Balkovi J., Basso B., Biernath K., Bindi M., Cammarano D., Challinor A.J., De Sanctis G., Dumont B., Eyshi Rezaei E., Fereres E., Ferrise R., Garcia - Vila M., Gayler S., Gao Y., Horan H., Hoogenboom G., César Izaurralde R., Jabloun M., Jones C.D., Kassie B.T., Kersebaum K.-Ch., Klein C., Koehler A.-K., Liu B., Minoli S., San Martin M.M., Müller C., Kumar S.N., Nendel C., Olesen J.E., Palosuo T., Porter J.R., Priesack E., Ripoche D., Semenov M.A., Stöckle S., Stratonovitch P., Streck T., Supit I., Tao F., Van der Velde M., Wallach D., Wang E., Webber H., Wolf J., Xiao L., Zhang Z., Zhao Z., 
Zhu Y., Ewert F. Climate change impact and adaptation for wheat protein. Global Change Biology, 2019, 25: 155-173 (doi: 10.1111/gcb.14481).

8. Lockyer S., White A., Buttriss J.L. Biofortified crops for tackling micronutrient deficiencies what impact are these having in developing countries and could they be of relevance within Europe? Nutrition Bulletin, 2018, 43: 319-357 (doi: 10.1111/nbu.12347).

9. Baez-Rogelio A., Morales-García Y.E., Quintero-Hernández V., Mucoz-Rojas J. Next generation of microbial inoculants for agriculture and bioremediation. Microbial Biotechnology, 2017, 10(1): 19-21 (doi: 10.1111/1751-7915.12448).

10. Ma Y. Beneficial bacteria for disease suppression and plant growth promotion. In: Plant-microbe interactions in agro-ecological perspectives. D. Singh, H. Singh, R. Prabha (eds.). Springer, Singapore, 2017: 513-529 (doi: 10.1007/978-981-10-5813-4_26).

11. Numan M., Bashir S., Khan Y., Mumtaz R., Shinwari Z.K., Khan A.L., Khan A., AL-Harrasi A. Plant growth promoting bacteria as an alternative strategy for salt tolerance in plants: a review. Microbiological Research, 2018, 209: 21-32 (doi: 10.1016/j.micres.2018.02.003).

12. Sarma B.K., Yadav K.S., Singh D.P., Singh H.B. Rhizobacteria mediated induced systemic tolerance in plants: prospects for abiotic stress management. In: Bacteria in Agrobiology: stress management. D. Maheshwari (ed.). Springer-Verlag, Berlin, Heidelberg, 2012: 225-238 (doi: 10.1007/9783-642-23465-1_11).

13. Lastochkina O., Aliniaeifard S., Kalhor M.S., Yuldashev R., Pusenkova L., Garipova S. Plant growth promoting bacteria - biotic strategy to cope with abiotic stresses in wheat. In: Wheat production in changing environments: Management, adaptation and tolerance /M. Hasanuzzaman, K. Nahar, A. Hossain (eds.). Springer, Singapore, 2019: 579-614 (doi: 10.1007/978-981-13-6883-7_23).

14. Awan S.A., Ilyas N., Khan I., Raza M.A., Rehman A.U., Rizwan M., Rastogi A., Tariq R., Brestic M. Bacillus siamensis reduces cadmium accumulation and improves growth and antioxidant defense system in two wheat (Triticum aestivum L.) varieties. Plants, 2020, 9: 878 (doi: 10.3390/plants9070878).

15. Velloso C.C.V., Ribeiro V.P., de Carvalho C.G., de Oliveira Christiane A.U., de Paula Lana G., Marriel I.E., de Sousa S.M., Gomes E.A. Tropical endophytic Bacillus species enhance plant growth and nutrient uptake in cereals. In: Endophytes: mineral nutrient management. Sustainable development and biodiversity. D.K. Maheshwari, S. Dheeman (eds.). Springer Nature, Switzerland, Cham, 2021: 157-180 (doi: 10.1007/978-3-030-65447-4_7).

16. Lastochkina O. Bacillus subtilis-mediated abiotic stress tolerance in plants. In: Bacilli and agrobiotechnology: phytostimulation and biocontrol. M.T. Islam, M.M. Rahman, P. Pandey, M.H. Boehme, G. Haesaert (eds.). Switzerland, Springer, 2019: 97-133 (doi: 10.1007/978-3-030-15175-1_6).

17. Sood G., Kaushal R., Sharma M. Significance of inoculation with Bacillus subtilis to alleviate drought stress in wheat (Triticum aestivum L.). Vegetos, 2020, 33: 782-792 (doi: 10.1007/s42535-020-00149-y).

18. Akram W., Anjum T., Ali B., Ahmad A. Screening of native Bacillus strains to induce systemic resistance in tomato plants against Fusarium wilt in split root system and its field applications. International Journal of Agriculture and Biology, 2013, 15: 1289-1294.

19. Lastochkina O., Seifi Kalhor M., Aliniaeifard S., Baymiev An., Pusenkova L., Garipova S., Kulabuhova D., Maksimov I. Bacillus spp.: efficient biotic strategy to control postharvest diseases of fruits and vegetables. Plants, 2019, 8(4): 97 (doi: 10.3390/plants8040097).

20. Maksimov I.V., Blagova D.K., Veselova S.V., Sorokan A.V., Burkhanova G.F., Cherepanova E.A., Sarvarova S.D., Rumyantsev V., Alekseev Yu., Khayrullin R.M. Recombinant Bacillus subtilis 26DCryChS line with gene Btcry1Ia encoding Cry1Ia toxin from Bacillus thuringiensis promotes integrated wheat defense against pathogen Stagonospora nodorum Berk. and greenbug Schizaphis graminum Rond. Biological Control, 2020, 144: 104242 (doi: 10.1016/j.biocontrol.2020.104242).

21. Cantoro R., Palazzini J.M., Yerkovich N., Miralles D.J., Chulze S.N. Bacillus velezensis RC 218 as a biocontrol agent against Fusarium graminearum: effect on penetration, growth and TRI5 expression in wheat spikes. Biological Control, 2021, 66: 259-270 (doi: 10.1007/s10526-020-10062-7).

22. Lastochkina O., Baymiev A., Shayahmetova A., Garshina D., Koryakov I., Shpirnaya I., Pusenkova L., Mardanshin I., Kasnak C., Palamutoglu R. Effects of endophytic Bacillus subtilis and salicylic acid on postharvest diseases (Phytophthora infestans, Fusarium oxysporum) development in stored potato tubers. Plants, 2020, 9: 76 (doi: 10.3390/plants9010076).

23. Miljakovic D., Marinkovic J., Balesevic-Tubic S. The significance of Bacillus spp. in disease suppression and growth promotion of field and vegetable crops. Microorganisms, 2020, 8: 1037 (doi: 10.3390/microorganisms8071037).

24. Cherif H., Marasco R., Rolli E., Ferjani R., Fusi M., Soussi A., Mapelli F., Blilou I., Borin S., Boudabous A., Cherif A., Daffonchio D., Ouzari H. Oasis desert farming selects environmentspecific date palm root endophytic communities and cultivable bacteria that promote resistance to drought. Environmental Microbiology Reports, 2015, 7: 668-678 (doi: 10.1111/1758-2229.12304).

25. Blake C., Christensen M.N., Kovács Б. Molecular aspects of plant growth promotion and protection by Bacillus subtilis. Molecular Plant-Microbe Interactions, 2021, 34(1): 15-25 (doi: 10.1094/MPMI-08-20-0225-CR).

26. Çakmakçı R., Turan M., Kıtır N., Güneş A., Nikerel E., Özdemir B.S., Yıldırım E., Olgun M., Topçuoğlu B., Tüfenkçi ş., Karaman M.R., Tarhan L., Mokhtari N.E.P. The role of soil beneficial bacteria in wheat production: a review. In: Wheat improvement, management and utilization. R. Wanyera, 
J. Owuoche (eds.). IntechOpen Limited, London, 2017: 115-149 (doi: 10.5772/67274).

27. Shobana N., Sugitha T., Sivakumar U. Plant growth-promoting Bacillus sp. cahoots moisture stress alleviation in rice genotypes by triggering antioxidant defense system. Microbiological Research, 2020, 239: 126518 (doi: 10.1016/j.micres.2020.126518).

28. Lastochkina O., Pusenkova L., Yuldashev R., Babaev M., Garipova S., Blagova D., Khairullin R., Aliniaeifard S. Effects of Bacillus subtilis on some physiological and biochemical parameters of Triticum aestivum L. (wheat) under salinity. Plant Physiology and Biochemistry, 2017, 121: 80-88 (doi: 10.1016/j.plaphy.2017.10.020).

29. Ilyas N., Mumtaz K., Akhtar N., Yasmin H., Sayyed R.Z., Khan W., Enshasy H.A.E., Dailin D.J., Elsayed E.A., Ali Z. Exopolysaccharides producing bacteria for the amelioration of drought stress in wheat. Sustainability, 2020, 12: 8876 (doi: 10.3390/su12218876).

30. Meenakshi S., Annapurna K., Govindasamy V., Ajit V., Choudhary D.K. Mitigation of drought stress in wheat crop by drought tolerant endophytic bacterial isolates. Vegetos, 2019, 32: 486-493 (doi: 10.1007/s42535-019-00060-1).

31. Lastochkina O., Garshina D., Allagulova C., Fedorova K., Koryakov I., Vladimirova A. Application of endophytic Bacillus subtilis and salicylic acid to improve wheat growth and tolerance under combined drought and Fusarium root rot stresses. Agronomy, 2020, 10: 1343 (doi: 10.3390/agronomy10091343).

32. Jochum M.D., McWilliams K.L., Borrego E.J., Kolomiets M.V., Niu G., Pierson E.A., Jo Y.K. Bioprospecting plant growth-promoting rhizobacteria that mitigate drought stress in grasses. Frontiers in Microbiology, 2019, 10: 2106 (doi: 10.3389/fmicb.2019.02106).

33. Hussain A., Ahmad M., Nafees M., Iqbal Z., Luqman M., Jamil M., Maqsood A., Mora-Poblete F., Ahmar S., Chen J.-T., Alyemeni M.N., Ahmad P. Plant-growth-promoting Bacillus and Paenibacillus species improve the nutritional status of Triticum aestivum L.. PLoS ONE, 2020, 15(12): e0241130 (doi: 10.1371/journal.pone.0241130).

34. Lastochkina O., Garshina D., Ivanov S., Yuldashev R., Khafizova R., Allagulova Ch., Fedorova K., Avalbaev A., Maslennikova D., Bosacchi M. Seed priming with endophytic Bacillus subtilis modulates physiological responses of two different Triticum aestivum L. cultivars under drought stress. Plants, 2020, 9(12): 1810 (doi: 10.3390/plants9121810).

35. Kaushal M. Portraying rhizobacterial mechanisms in drought tolerance: a way forward toward sustainable agriculture. In: PGPR amelioration in sustainable agriculture. A.K. Singh, A. Rumar, P.K. Singh (eds.). Elsevier Inc., 2019: 195-216 (doi: 10.1016/B978-0-12-815879-1.00010-0).

36. Oleńska E., Małek W., Wójcik M., Swiecicka I., Thijs S., Vangronsveld J. Beneficial features of plant growth-promoting rhizobacteria for improving plant growth and health in challenging conditions: a methodical review. Science of the Total Environment, 2020, 743: 140682 (doi: 10.1016/j.scitotenv.2020.140682).

37. Baig K.S., Arshad M., Shaharoona B., Khalid A., Ahmed I. Comparative effectiveness of Bacillus spp. possessing either dual or single growth-promoting traits for improving phosphorus uptake, growth and yield of wheat (Triticum aestivum L.). Annals of Microbiology, 2012, 62(3): 1109-1119 (doi: 10.1007/s13213-011-0352-0).

38. Saha M., Sarkar S., Sarkar B., Sharma B.K., Bhattacharjee S., Tribedi P. Microbial siderophores and their potential applications: a review. Environmental Science and Pollution Research, 2016, 23(5): 3984-3999 (doi: 10.1007/s11356-015-4294-0).

39. Kumar A., Ram Maurya B., Raghuwanshi R. The microbial consortium of indigenous rhizobacteria improving plant health, yield and nutrient content in wheat (Triticum aestivum). Journal of Plant Nutrition, 2021, 44(13): 1942-1956 (doi: 10.1080/01904167.2021.1884706).

40. Timmusk S., Abd El-Daim I.A., Copolovici L., Tanilas T., Kдnnaste A., Behers L., Nevo E., Seisenbaeva G., Stenstrцm E., Niinemets b. Drought-tolerance of wheat improved by rhizosphere bacteria from harsh environments: enhanced biomass production and reduced emissions of stress volatiles. PLoS ONE, 2014, 9(5): e96086 (doi: 10.1371/journal.pone.0096086).

41. Abd El-Daim I.A., Bejai S., Meijer J. Bacillus velezensis 5113 induced metabolic and molecular reprogramming during abiotic stress tolerance in wheat. Scientific Reports, 2019, 9: 16282 (doi: 10.1038/s41598-019-52567-x).

42. Kaushal M. Microbes in cahoots with plants: MIST to hit the jackpot of agricultural productivity during drought. International Journal of Molecular Sciences, 2019, 20: 1769 (doi: 10.3390/ijms20071769).

43. Abd El-Daim I.A., Bejai S., Fridborg I., Meijer J. Identifying potential molecular factors involved in Bacillus amyloliquefaciens 5113 mediated abiotic stress tolerance in wheat. Plant Biology, 2018, 20: 271-279 (doi: 10.1111/plb.12680).

44. Zafar-ul-Hye M., Danish S., Abbas M., Ahmad M., Munir T.M. ACC deaminase producing PGPR Bacillus amyloliquefaciens and Agrobacterium fabrum along with Biochar improve wheat productivity under drought stress. Agronomy, 2019, 9: 343 (doi: 10.3390/agronomy9070343).

45. Danish S., Zafar-ul-Hye M., Hussain M., Shaaban M., Núcez-Delgado A., Hussain S., Qayyum M.F. Rhizobacteria with ACC-deaminase activity improve nutrient uptake, chlorophyll contents and early seedling growth of wheat under PEG-induced osmotic stress. International Journal of Agriculture and Biology, 2019, 21: 1212-1220 (doi: 10.17957/IJAB/15.1013).

46. Danish S., Zafar-ul-Hye M. Co-application of ACC-deaminase producing PGPR and timberwaste biochar improves pigments formation, growth and yield of wheat under drought stress. 
Scientific Reports, 2019, 9: 5999 (doi: 10.1038/s41598-019-42374-9).

47. Zhang H., Murzello C., Sun Y., Kim M.S., Xie X., Jeter R.M., Zak J.C., Dowd S.E., Pare P.W. Choline and osmotic-stress tolerance induced in Arabidopsis by the soil microbe Bacillus subtilis (GB03). Molecular Plant-Microbe Interactions, 2010, 23: 1097-1104 (doi: 10.1094/MPMI-23-8-1097).

48. Su A.Y., Niu S.Q., Liu Y.Z., He A.L., Zhao Q., Parй P.W., Li M.F., Han Q.Q., Ali Khan S., Zhang J.L. Synergistic effects of Bacillus amyloliquefaciens (GB03) and water retaining agent on drought tolerance of perennial ryegrass. International Journal of Molecular Sciences, 2017, 18(12): 2651 (doi: 10.3390/ijms18122651).

49. Zhang N., Yang D., Wang D., Miao Y., Shao J., Zhou X., Xu Z., Li Q., Feng H., Li S., Shen Q., Zhang R. Whole transcriptomic analysis of the plant-beneficial rhizobacterium Bacillus amyloliquefaciens SQR9 during enhanced biofilm formation regulated by maize root exudates. $B M C G e$ nomics, 2015, 16: 685 (doi: 10.1186/s12864-015-1825-5).

50. Khan N., Bano A. Exopolysaccharide producing rhizobacteria and their impact on growth and drought tolerance of wheat grown under rainfed conditions. PLoS ONE, 2019, 14(9): e0222302 (doi: 10.1371/journal.pone.0222302).

51. Gowtham H.G., Brijesh S.S., Murali M., Shilpa N., Melvin P., Mohammed A., Amruthesh K.N., Niranjana S.R. Induction of drought tolerance in tomato upon the application of ACC deaminase producing plant growth promoting rhizobacterium Bacillus subtilis Rhizo SF 48. Microbiological Research, 2020, 234: 126422 (doi: 10.1016/j.micres.2020.126422).

52. Rashid U., Yasmin H., Hassan M.N., Naz R., Nosheen A., Sajjad M., Ilyas N., Keyani R., Jabeen Z., Mumtaz S., Alyemeni M.N., Ahmad P. Drought-tolerant Bacillus megaterium isolated from semi-arid conditions induces systemic tolerance of wheat under drought conditions. Plant Cell Reports, 2021, a Collection: 1-21 (doi: 10.1007/s00299-020-02640-x).

53. Amna, Ud Din B., Sarfraz S., Xia Y., Kamran M.A., Javed M.T., Sultan T., Munis M.F.H., Chaudhary H.J. Mechanistic elucidation of germination potential and growth of wheat inoculated with exopolysaccharide and ACC-deaminase producing Bacillus strains under induced salinity stress. Ecotoxicology and Environmental Safety, 2019, 183: 109466 (doi: 10.1016/j.ecoenv.2019.109466).

54. Salem G., Stromberger M.E., Byrne P.F., Manter D.K., El-Feki W., Weir T.L. Genotype-specific response of winter wheat (Triticum aestivum L.) to irrigation and inoculation with ACC deaminase bacteria. Rhizosphere, 2018, 8: 1-7 (doi: 10.1016/j.rhisph.2018.08.001).

55. Pusenkova L.I., Garipova S.R., Lastochkina O.V., Yuldashev R.A. Problemy agrokhimii i ekologii, 2020, 3: 56-64 (doi: 10.26178/AE.2020.19.55.005) (in Russ.).

56. Pishchik V.N., Vorob'ev N.I., Moiseev K.G., Sviridova O.V., Surin V.G. Pochvovedenie, 2015, 1: 87-94 (doi: 10.7868/S0032180X1501013X) (in Russ.).

57. Ramesh A., Sharma S.K., Yadav N., Joshi O.P. Phosphorus mobilization from native soil P-pool upon inoculation with phytate-mineralizing and phosphate-solubilizing Bacillus aryabhattai isolates for improved P-acquisition and growth of soybean and wheat crops in microcosm conditions. Agricultural Research, 2014, 3: 118-127 (doi: 10.1007/s40003-014-0105-y).

58. Kour D., Rana K.L., Yadav A.N., Yadav N., Kumar V., Kumar A., Sayyed R.Z., Hesham A.E.-L., Dhaliwal H.S., Saxena A.K. Drought-tolerant phosphorus-solubilizing microbes: Biodiversity and biotechnological applications for alleviation of drought stress in plants. In: Plant growth promoting rhizobacteria for sustainable stress management. Microorganisms for sustainability. R. Sayyed, N. Arora, M. Reddy (eds.). Springer, Singapore, 2019: 255-308 (doi: 10.1007/978-981-13-65362_13).

59. Rodríguez H., Gonzalez F.T., Bashan Y. Genetics of phosphate solubilization and its potential applications for improving plant growth-promoting bacteria. Plant and Soil, 2006, 287(1-2): 15 21 (doi: 10.1007/s11104-006-9056-9).

60. Ramesh A., Sharma S.K., Sharma M.P., Yadav N., Joshi O.P. Inoculation of zinc solubilizing Bacillus aryabhattai strains for improved growth, mobilization and biofortification of zinc in soybean and wheat cultivated in Vertisols of central India. Applied Soil Ecology, 2014, 73: 87-96 (doi: 10.1016/j.apsoil.2013.08.009).

61. Albelda-Berenguer M., Monachon M., Joseph E. Siderophores: from natural roles to potential applications. Advances in Applied Microbiology, 2019, 106: 193-225 (doi: 10.1016/bs.aambs.2018.12.001).

62. Beck E.H., Fetitig S., Knake C., Hartig K., Bhattarai T. Specific and unspecific responses of plants to cold and drought stress. Journal of Biosciences, 2007, 32: 501-510 (doi: 10.1007/s12038007-0049-5).

63. Barnawal D., Bharti N., Pandey S.S., Pandey A., Chanotiya C.S., Kalra A. Plant growth promoting rhizobacteria enhances wheat salt and drought stress tolerance by altering endogenous phytohormone levels and TaCTR1/TaDREB2 expression. Physiologia Plantarum, 2017, 161: $502-$ 514 (doi: 10.1111/ppl.12614).

64. Sharma M.P., Grover M., Chourasiya D., Bharti A., Agnihotri R., Maheshwari H.S., Pareek A., Buyer J.S., Sharma S.K., Schütz L., Mathimaran N., Singla-Pareek S.L., Grossman J.M., Bagyaraj D.J. Deciphering the role of trehalose in tripartite symbiosis among rhizobia, arbuscular mycorrhizal fungi, and legumes for enhancing abiotic stress tolerance in crop plants. Frontiers in Microbiology, 2020, 11: 509919 (doi: 10.3389/fmicb.2020.509919).

65. Yadav R., Ror P., Rathore P., Kumar S., Ramakrishna W. Bacillus subtilis CP4, isolated from 
native soil in combination with arbuscular mycorrhizal fungi promotes biofortification, yield and metabolite production in wheat under field conditions. Journal of Applied Microbiology, 2021, 131(1): 339-359 (doi: 10.1111/jam.14951).

66. Zhou C., Ma Z., Zhu L., Xia X., Xie Y., Zhu J., Wang J. Rhizobacterial strain Bacillus megaterium BOFC15 induces cellular polyamine changes that improve plant growth and drought resistance. International Journal of Molecular Sciences, 2016, 17: 976 (doi: 10.3390/ijms17060976).

67. Naseem H., Ahsan M., Shahid M.A., Khan N. Exopolysaccharides producing rhizobacteria and their role in plant growth and drought tolerance. Journal of Basic Microbiology, 2018, 58(12): 1009-1022 (doi: 10.1002/jobm.201800309).

68. Kasim W.A., Osman M.E., Omar M.N., Abd El-Daim I.A., Bejai S., Meijer J. Control of drought stress in wheat using plant-growth-promoting bacteria. Journal of Plant Growth Regulation, 2013, 32: 122-130 (doi: 10.1007/s00344-012-9283-7).

69. Eichmann R., Richards L., Schäfer P. Hormones as go - betweens in plant microbiome assembly. Plant Journal, 2021, 105(2): 518-541 (doi: 10.1111/tpj.15135).

70. Camaille M., Fabre N., Clément C., Ait Barka E. Advances in wheat physiology in response to drought and the role of plant growth promoting rhizobacteria to trigger drought tolerance. Microorganisms, 2021, 9: 687 (doi: 10.3390/microorganisms9040687).

71. Sivasakthi S., Kanchana D., Usharani G., Saranraj P. Production of plant growth promoting substance by Pseudomonas fluorescens and Bacillus subtilis isolated from paddy rhizosphere soil of Cuddalore district, Tamil Nadu, India. International Journal of Microbiology Research, 2013, 4(3): 227-233 (doi: 10.5829/idosi.ijmr.2013.4.3.75171).

72. Ishak Z., Mohd Iswadi M.K., Russman Nizam A.H., Ahmad Kamil M.J., Ernie Eileen R.R., Wan Syaidatul A., Ainon H. Plant growth hormones produced by endophytic Bacillus subtilis strain LKM-BK isolated from cocoa. Malaysian Cocoa Journal, 2016, 9(1): 127-133.

73. Moon S., Asif R., Basharat A. Phylogenetic diversity of drought tolerant Bacillus spp. and their growth stimulation of Zea mays L. under different water regimes. Research Journal of Biotechnology, 2017, 12(10): 38-46.

74. Ahmad Z., Wu J., Chen L., Dong W. Isolated Bacillus subtilis strain 330-2 and its antagonistic genes identified by the removing PCR. Scientific Reports, 2017, 7(1): 1777 (doi: 10.1038/s41598017-01940-9).

75. Khalid A., Arshad M., Zahir Z.A. Screening plant growth promoting rhizobacteria for improving growth and yield of wheat. Journal of Applied Microbiology, 2004, 96: 473-480 (doi: 10.1046/j.13652672.2003.02161.x).

76. Egamberdieva D., Kucharova Z. Selection for root colonising bacteria stimulating wheat growth in saline soils. Biology and Fertility of Soils, 2009, 45(6): 563-571 (doi: 10.1007/s00374-009-0366-y).

77. Sessitsch A., Hardoim P., Döring J., Weilharter A., Krause A., Woyke T., Mitter B., HaubergLotte L., Friedrich F., Rahalkar M., Hurek T., Sarkar A., Bodrossy L., van Overbeek L., Brar D., van Elsas J.D., Reinhold-Hurek B. Functional characteristics of an endophyte community colonizing rice roots as revealed by metagenomic analysis. Molecular Plant-Microbe Interactions, 2012, 25(1): 28-36 (doi: 10.1094/MPMI-08-11-0204).

78. Pandey P.K., Singh M.C., Singh S.S., Kumar A.K., Pathak M.M., Shakywar R.C., Pandey A.K. Inside the plants: endophytic bacteria and their functional attributes for plant growth promotion. International Journal of Current Microbiology and Applied Sciences, 2017, 6(2): 11-21 (doi: 10.20546/ijcmas.2017.602.002).

79. Kuklinski-Sorbal J., Araujo W.L., Mendes R., Geraldi I.O., Pizzirani-Kleiner A.A., Azevedo J.L. Isolation and characterization of soybean-associated bacteria and their potential for plant growth promotion. Environmental Microbiology, 2004, 6(12): 1244-1251 (doi: 10.1111/j.1462-2920.2004.00658.x).

80. Gutiérrez - Macero F.J., Ramos B., Probanza A., Mehouachi J., Talon M. The plant growth promoting rhizobacteria Bacillus pumilus and Bacillus licheniformis produce high amounts of physiologically active gibberelins. Physiologia Plantarum, 2008, 111: 206-221 (doi: 10.1034/j.13993054.2001.1110211.x).

81. Huang D., Wu W., Abrams S.R., Cutler A.J. The relationship of drought-related gene expression in Arabidopsis thaliana to hormonal and environmental factors. Journal of Experimental Botany, 2008, 59: 2991-3007 (doi: 0.1093/jxb/ern155).

82. Kang S.-M., Khan A.L., Waqas M., You Y.-H., Kim J.H., Kim J.-G., Hamayun M., Lee I.-J. Plant growth-promoting rhizobacteria reduce adverse effects of salinity and osmotic stress by regulating phytohormones and antioxidants in Cucumis sativus. Journal of Plant Interactions, 2014, 9(1): 673-682 (doi: 10.1080/17429145.2014.894587).

83. Niu D., Wang X., Wang Y., Song X., Wang J., Guo J., Zhao H. Bacillus cereus AR156 activates PAMP-triggered immunity and induces a systemic acquired resistance through a NPR1-and SAdependent signaling pathway. Biochemical and Biophysical Research Communication, 2016, 469(1): 120-125 (doi: 10.1016/j.bbrc.2015.11.081).

84. Leelasuphakul W., Sivanunsakul P., Phongpaichit S. Purification, characterization and synergistic activity of $\beta$-1,3-glucanase and antibiotic extract from an antagonistic Bacillus subtilis NSRS 8924 against rice blast and sheath blight pathogens. Enzyme and Microbial Technology, 2006, 38: 990-997 (doi: 10.1016/j.enzmictec.2005.08.030). 
85. Etesami H., Beattie G.A. Plant-microbe interactions in adaptation of agricultural crops to abiotic stress conditions. In: Probiotics and health. V. Kumar, M. Kumar, S. Sharma, R. Prasad (eds.). Springer, Singapore, 2017: 163-200 (doi: 10.1007/978-981-10-3473-2_7).

86. Seifikalhor M., Aliniaeifard S., Hassani B., Niknam V., Lastochkina O. Diverse role of $\gamma$-aminobutyric acid in dynamic plant cell responses. Plant Cell Reports, 2019, 38: 847-867 (doi: 10.1007/s00299-019-02396-z).

87. Gagné-Bourque F., Bertrand A., Claessens A., Aliferis K.A., Jabaji S. Alleviation of drought stress and metabolic changes in timothy (Phleum pratense L.) colonized with Bacillus subtilis B26. Frontiers in Plant Science, 2016, 7: 584 (doi: 10.3389/fpls.2016.00584).

88. Lastochkina O.V., Yuldashev R.A., Pusenkova L.I. Izvestiya UNTS RAN, 2017, 3(1): 99-102 (in Russ.).

89. Martins S.J., Medeiros F.H.V., Lakshmanan V., Bais H.P. Impact of seed exudates on growth and biofilm formation of Bacillus amyloliquefaciens ALB629 in common bean. Frontiers in Microbiology, 2018, 8: 2631 (doi: 10.3389/fmicb.2017.02631).

90. Olanrewaju O.S., Ayangbenro A.S., Glick B.R., Babalola O.O. Plant health: Feedback effect of root exudates-rhizobiome interactions. Applied Microbiology and Biotechnology, 2019, 103: 11551166 (doi: 10.1007/s00253-018-9556-6).

91. Abedinzadeh M., Etesami H., Alikhani H.A. Characterization of rhizosphere and endophytic bacteria from roots of maize (Zea mays L.) plant irrigated with wastewater with biotechnological potential in agriculture. Biotechnology Reports, 2019, 21: e00305 (doi: 10.1016/j.btre.2019.e00305).

92. Li Y., Shi H., Zhang H., Chen S. Amelioration of drought effects in wheat and cucumber by the combined application of super absorbent polymer and potential biofertilizer. PeerJ, 2019, 7: e6073 (doi: 10.7717/peerj.6073).

93. Baris O., Sahin F., Turan M., Orhan F., Gulluce M. Use of plant-growth-promoting rhizobacteria (PGPR) seed inoculation as alternative fertilizer inputs in wheat and barley production. Communications in Soil Science and Plant Analysis, 2014, 45(18): 2457-2467 (doi: 10.1080/00103624.2014.912296).

94. Afzal A., Saleem S., Iqbal Z., Jan G., Malik M.F.A., Asad S.A. Interaction of rhizobium and Pseudomonas with wheat (Triticum aestivum L.) in potted soil with or without P2O5. Journal of Plant Nutrition, 2014, 37(13): 2144-2156 (doi: 10.1080/01904167.2014.920374).

95. Germida J., Walley F. Plant growth-promoting rhizobacteria alter rooting patterns and arbuscular mycorrhizal fungi colonization of field-grown spring wheat. Biology and Fertility of Soils, 1996, 23(2): 113-120 (doi: 10.1007/BF00336050).

96. Mushtaq Z. PGPR: present role, mechanism of action and future prospects along bottlenecks in commercialization. International Journal of Environmental Quality, 2021, 41: 9-15 (doi: 10.6092/issn.22814485/11103). 